CHONG-EN BAI

Tsinghua University

CHANG-TAI HSIEH

University of Chicago

ZHENG (MICHAEL) SONG

Chinese University of Hong Kong

\title{
The Long Shadow of China's \\ Fiscal Expansion
}

ABSTRACT In 2009 and 2010, China undertook a fiscal stimulus program worth 4 trillion yuan, roughly equivalent to 11 percent of its annual GDP. This program was largely financed by off-balance-sheet companies-known as local financing vehicles - that both borrowed and spent on behalf of local governments. These companies have continued to grow since the stimulus program concluded at the end of 2010; their spending has accounted for roughly 10 percent of GDP each year, with an increasing share used for what are essentially commercial projects. And their spending has likely been responsible for an increase of 5 percentage points in the aggregate investment rate and for part of the decline of 7 to 8 percentage points in the current account surplus since 2008. We argue that local governments have used their new access to financial resources to facilitate favored businesses' access to capital, which potentially worsens the overall efficiency of capital allocation. The long-run effect of offbalance-sheet spending by local governments may be a permanent decline in the growth rate of aggregate productivity and GDP.

n November 2008, in the depths of the global financial crisis, China announced with great fanfare a fiscal stimulus program worth 4 trillion yuan, to be spent by 2010. In response to the announcement of this program, Dominique Strauss-Kahn, then the managing director of the International Monetary Fund, said that "it will have an influence not only on the world economy in supporting demand but also a lot of influence on the Chinese economy itself, and I think it is good news for correcting imbalances" (Barboza 2008). The program funds, amounting to about 11 percent 
of China's annual GDP, were mostly to be spent on infrastructure projects in 2009 and 2010. Many people viewed the program as playing an important role in preventing the worldwide recession from getting worse. Paul Krugman wrote in 2010 that China had engaged in a "much more aggressive stimulus than any Western nation—and it has worked out well" (Krugman 2010).

The goal of this paper is twofold. First, we analyze the institutional details of how China financed its fiscal stimulus program. We show that the stimulus was implemented by local governments and was mostly financed through the relaxation of the financial constraints faced by these local governments. Specifically, although local governments were legally prohibited from borrowing or running deficits, to circumvent these restrictions, in 2009 and 2010 local governments were allowed to create off-balance-sheet companies, known as local financing vehicles (LFVs), to fund the stimulus spending. A typical arrangement would be for a local government to transfer ownership of a plot of land to an LFV, and then the LFV would use the land as collateral to borrow from banks and shadow banks (trust products), as well as to issue bonds.

Figure 1 plots the investment rate and the budget deficit, with vertical lines drawn at the beginning and end of the stimulus program. As can be seen, the investment rate increased by about 4 percent of GDP in 2009 and 2010, suggesting that much of the fiscal stimulus was spent, as planned, on public infrastructure projects. However, it can also be seen that there was a much smaller increase in the Chinese government's official budget deficit. ${ }^{1}$ We show that this gap between the increase in the investment rate and the budget deficit was bridged by the new LFVs' off-balance-sheet spending.

Second, in this paper we assess the consequences of this financing choice after the stimulus program ended in 2010. We argue that throughout this period, local governments were actively providing special deals to favored businesses, but could not borrow from or influence the lending decisions of state-owned banks. The effect was that the assistance provided by local governments to favored firms largely consisted of exemptions from the country's thicket of rules and regulations, but local governments could not provide the private firms they were trying to assist with preferential access to capital. These two institutional features-high-powered incentives to provide special deals, along with restrictions on access to capital—explain how China was able to grow rapidly despite seemingly low-quality institutions.

1. The figure shows the combined budget deficit of the central and local governments. 
Figure 1. Investment Rate and Budget Deficit, 2000-14

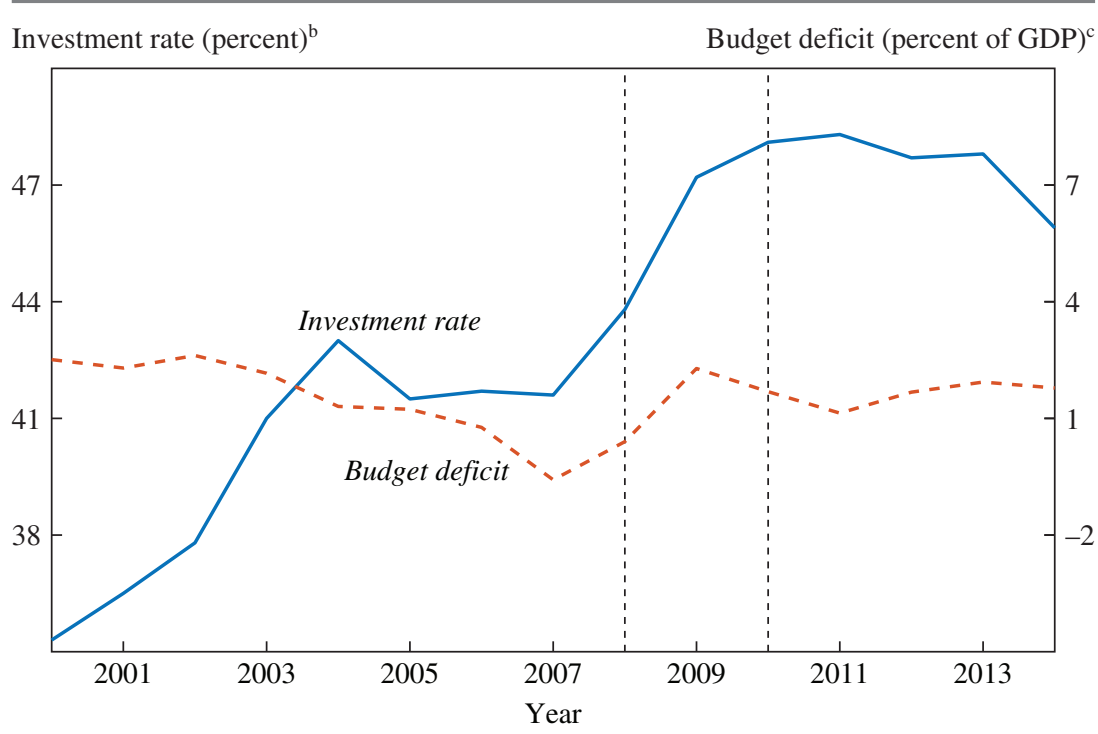

Source: National Bureau of Statistics of China.

a. The vertical lines indicate the beginning and end of the stimulus program worth 4 trillion yuan.

b. The investment rate is the gross fixed capital formation series provided by the National Bureau of Statistics.

c. The total deficit is the sum of the central and local government deficits.

We show that the off-balance-sheet financial institutions created to fund the fiscal stimulus program changed the nature of the special-deals regime. Specifically, we show that the off-balance-sheet financial institutions continued to grow even after the stimulus program was over, because local governments now had a powerful new tool, the LFVs, to provide support for favored firms. As partial evidence, figure 1 shows that the investment rate remained higher (compared with 2008) even after the end of the fiscal stimulus in 2010. By 2014, the investment rate stood at 48 percent of GDP, which is probably the highest investment rate of any country in the world. The increase in the investment rate since 2008 reflects spending by local governments financed through the LFVs, and is a direct consequence of the financing choices made in 2009 and 2010.

In short, the fiscal stimulus was really a partial financial liberalization. It was only partial because financial constraints were lifted only for local governments, and not for private financial institutions or state-owned banks. This might have had positive effects on welfare and growth if local governments had used these resources for projects that would have high 
Figure 2. Quarterly GDP Growth Rate, 2000-16

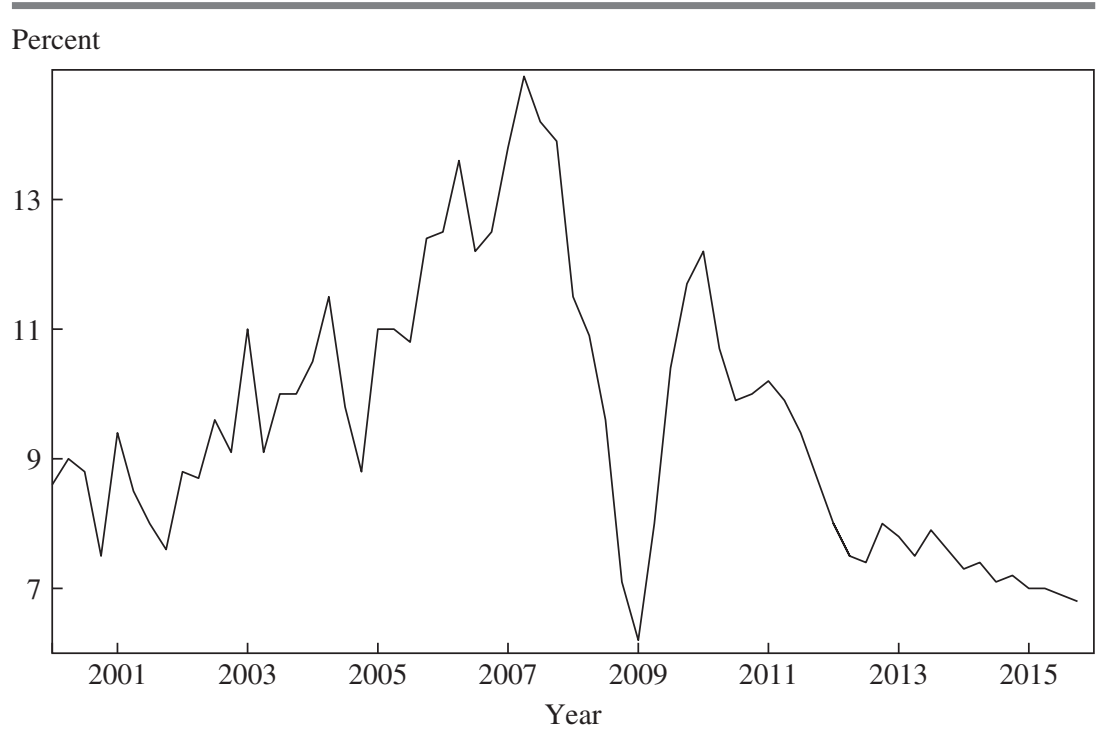

Source: National Bureau of Statistics of China.

social returns but had been starved of resources. However, we provide evidence that in addition to funding infrastructure projects, the relaxation of financial constraints also made it possible for local governments to channel financial resources to commercial projects favoring certain firms. In 2014 and 2015, we estimate that the off-balance-sheet spending by local governments accounted for about 11 percent of GDP, of which 2.4 percent was spent on local infrastructure projects and 8.6 percent on what are essentially private commercial projects. The aggregate effect is that the overall efficiency in the allocation of capital worsened, which, ceteris paribus, lowers the aggregate growth rate.

The net effect is that despite the increase in the investment rate since 2008, aggregate growth rates have declined significantly (see figure 2). There are clearly many other forces behind the slowdown in Chinese growth, and we do not attempt to draw these out here; but the long shadow of the Chinese fiscal stimulus driven by the behavior of local governments is likely an important force. Moreover, we document that despite numerous attempts by the Chinese central government to roll back LFVs' offbalance-sheet borrowing, this has thus far proven very difficult to do. We conclude that if changes are not made, this does not augur well for future 
Chinese growth, with potentially large spillover effects on growth in other regions of the world.

The paper proceeds as follows. We first describe the key institutional features behind China's growth in the two decades preceding the fiscal stimulus program. We then lay out the program's key facts, before describing the growth of the off-balance-sheet financial institutions. We then use data from a sample of these institutions, as well as firm-level data from the Chinese Industrial Survey, to provide microeconomic evidence of the effect of the institutions created by the fiscal stimulus.

\section{Growth under Special Deals and Financial Constraints}

To understand the long-run effects of China's 2009-10 fiscal stimulus program, it is useful to take a step back and analyze the institutional foundations of the country's growth. The conventional narrative of China's growth is that it reflects the gradual improvement of the country's institutions. Specifically, growth took off when China removed the constraints faced by farmers, opened up to the world, regularized its economic and political institutions after the turmoil of the Cultural Revolution, and generally introduced promarket institutions. Although this narrative likely includes an important part of what happened in the 1980s, it is probably not the right explanation for what happened after 1989. Yasheng Huang (2008), for example, documents that many of the promarket policies adopted in the 1980s were reversed after 1989. Another piece of evidence is provided by the World Bank's Doing Business indicators, a widely used measure of the friendliness of a country's institutional environment vis-à-vis the private sector. According to these indictors, in 2013 China ranked 151 in the world in terms of the ease of "starting a business." This was roughly on par with the Democratic Republic of the Congo's ranking (149), and significantly below those of Iran (87), Pakistan (98), and Syria (132). ${ }^{2}$

However, if the institutions supporting private firms are as bad as suggested by the narrative evidence and the World Bank's Doing Business indicators, what explains the explosive growth in China's private sector during the last 20 years? In a companion paper (Bai, Hsieh, and Song 2016), we argue that the key to China's growth is the development of an informal regime of "special deals" for private firms, combined with strict

2. These rankings are from the 2013 annual report. For more information on these indicators, see http://www.doingbusiness.org. 
financial constraints over local governments. We argue that a sine qua non for successful private firms in China is that they need to have the political support of a local Communist Party boss. This is because, as suggested by the World Bank's Doing Business indicators, the environment of formal institutions for private firms is very bad in China. In this environment, the only way for a private firm to succeed is for it to manage to enter into a relationship with a political leader that allows it to circumvent the formal rules. This situation is common for private firms in other countries with weak formal institutions, and China is no different.

However, the outcome, in terms of the growth of private firms and aggregate growth more generally, appears to be different in China compared with other countries that have seemingly similar regimes. Why is China different? For the purposes of this paper, a key feature of the Chinese system is that local governments (at the level of counties and prefectures) have enormous power, and they have largely used this power in the last 20 years to support a subset of private firms, but they did not have access to financial resources. This was an important factor in forcing local governments to support favored private firms by improving their institutional environment. This support primarily took the form of exemptions from official rules and of lobbying the central government for special exemptions from the rules. But local governments still could not provide financial support to their favored private firms. And these severe budget constraints also meant that little could be directly stolen from the public budget.

Three key institutional reforms in the 1990s created the severe budget constraints faced by local governments. Until the early 1990s, taxes were largely under the control of local governments. In 1994, for example, almost 80 percent of all tax revenues were collected and spent by local governments (see figure 3). Under this system, known as the "fiscal contract responsibility system," local governments had to make fixed or regressive payments to the central government but could keep the remainder of local taxes. ${ }^{3}$

The "tax-sharing reform" of 1994 removed local governments' control over the allocation of local tax revenues. As can be seen in figure 3, in 1994 the tax share of local governments fell from almost 80 percent to

3. There are five contractual arrangements for the tax sharing between the central and provincial governments. Most of the contracts imply that local fiscal revenues outgrow remittances to the central government. Only three provinces remit a fixed share of local revenue to the central government. For more institutional details, see Jiang (2008) and Jin, Qian, and Weingast (2005). 
Figure 3. The Share of Total Tax Revenues Collected and Spent by Local Governments, 1984-2013

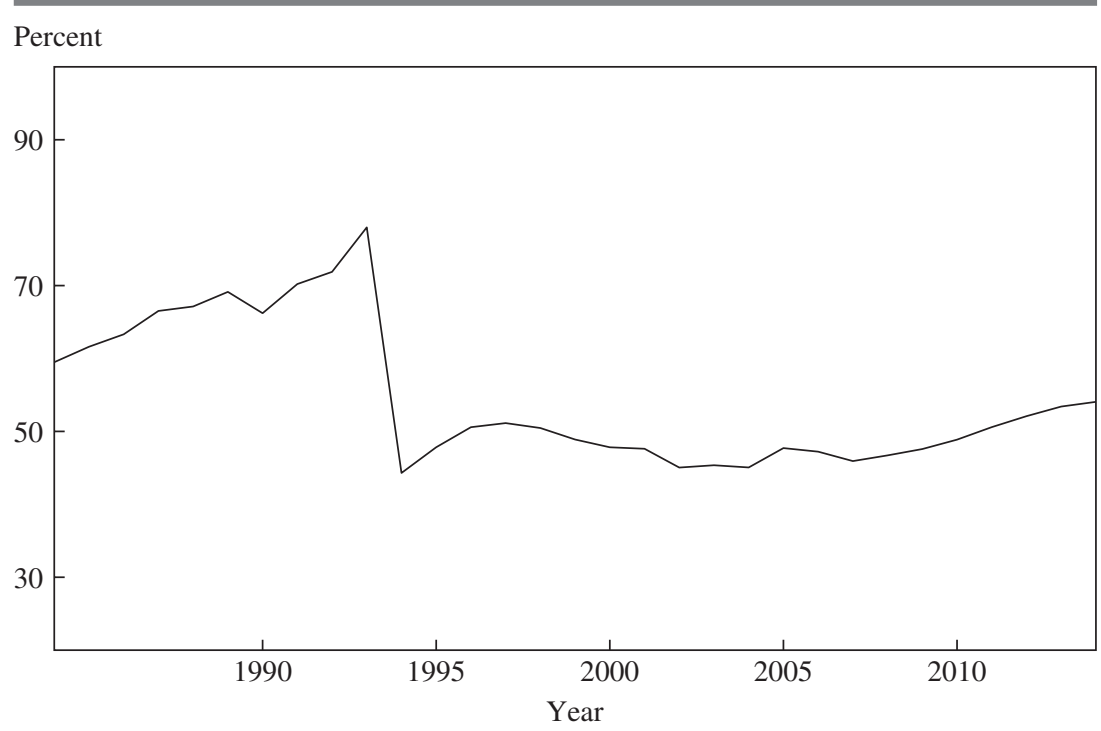

Source: China Statistical Yearbook.

50 and then 40 percent. The central government made fiscal transfers to local governments, but it tied these transfers to specific spending projects, at least for the wealthier local governments. For these wealthier localities, more than 80 percent of the transfers from the central government were earmarked for specific projects or transfers, particularly social security and welfare programs. ${ }^{4}$

To be sure, local governments responded by looking for other sources of revenue. Many local governments began to impose penalties on legal violations and to charge fees for access to "public" services. More important, many local governments seized land from farmers and urban residents and resold the land to private firms and developers. Land sales have become an important source of local revenue; but because land is a fixed resource, revenues from land sales had mostly leveled off by 2014 . Furthermore, there were controls over how revenues from land sales could be used.

A second important change was that the 1994 Budget Law made it illegal for local governments to incur budget deficits. This is not to say that there was not some wiggle room. It was possible for local governments

4. For a review on the tax-sharing reform, see Wong and Bird (2008). 
to implicitly run up deficits by establishing locally controlled, state-owned companies - the original LFVs-whose explicit purpose was to borrow for public spending. Before 2009, these types of companies were severely restricted. Only two types of LFVs were allowed: (i) companies specializing in road and bridge construction, and (ii) investment companies specializing in urban development. ${ }^{5}$ Nonetheless, only a small number of local governments were able to obtain access to resources via this channel. For example, only $17 \mathrm{LFV}$ s issued bonds in $2006 .{ }^{6}$ In addition, as we document in detail below, in 2008 the implicit local government debt was less than 6 trillion yuan, or about 20 percent of China's GDP in that year.

The third change that came in the late 1990s was the reorganization of state-owned banks, which was implemented by Premier Zhu Rongji. Before the late 1990s, Zhou Xiaochuan, the governor of the People's Bank of China, described the incentives of local banking officials as follows:

Loan allocation, like administrative jurisdiction, seems to be decentralized by province, prefecture, city, and county. Local branches at each level may exhibit the phenomenon of "three eyes," that is, "three eyes" were watching the headquarters, local governments, and local branches of the People's Bank of China. (Zhou 2004)

The consequence of this "three-eyed" system was that local officials were able to exercise their political influence over the banks by allocating loans to their pet projects. In 1997 and 1998, using the Asian financial crisis as an excuse, the central government pushed through a new vertical management system for the state-owned banks. Under this system, the provincial branches of the People's Bank of China were dismantled and replaced with nine branches that crossed several provinces. It was particularly important that the power of local Communist Party officials over the appointments of local bank officers was removed and centralized by the People's Bank of China. This power was further centralized in 2003, when the China Banking Regulatory Commission (CBRC) was established (Zhu 2011, pp. 475-91).

As a result, the banking sector became more competitive (Hachem and Song 2016). The nonperforming loan rate, which reached a record high of 30 percent in the late 1990s and early 2000s, declined to below 3 percent in 2008. The reformed banking sector managed to resist mounting pressure from local governments that had been desperately looking for external financing since the tax-sharing reform. One example is the effort made

5. Bai and Qian (2010) provide case studies of these companies.

6. This information is from the Wind database, which we describe later in the paper. 
by the CBRC to prohibit local governments from providing guarantees on loans except for those approved by the State Council.

\section{The 4 Trillion Yuan Fiscal Stimulus}

The Chinese economy was hit hard by the 2008 global financial crisis. GDP growth fell to 7.1 percent in the fourth quarter of 2008, down from 13.9 percent in 2007 in the same quarter (see figure 2). The unemployment rate among registered urban households rose by 2 percentage points in 2008, which almost certainly understates the increase in the unemployment rate among nonregistered urban households. ${ }^{7}$ In response, the Chinese authorities rolled out a program of stimulus measures in November 2008, of which the most important was the fiscal stimulus of 4 trillion yuan, to be spent by $2010 .^{8}$

The left side of table 1 summarizes planned investment under the stimulus program in seven broad categories. According to the program, about half the stimulus (1.87 trillion yuan) was to be spent on public infrastructure projects, and one-quarter on infrastructure repairs in response to the 2008 Wenchuan earthquake. The table's remaining columns present the information from the published budgets of local and central governments in roughly the same seven categories in 2009 and 2010. We use the word "roughly" because the classification of spending in the published budgets does not match the spending categories in the stimulus program. For clarity, table 1 lists the spending categories in the published budget that we are able to match with the categories in the stimulus program. We call this on-balance-sheet spending. In the absence of a fiscal stimulus program, we assume that realized spending in the seven spending categories would have remained constant as a share of GDP. We then estimate the stimulus's effect as the difference between on-balance-sheet spending in 2009 and 2010 and the no-stimulus counterfactual. ${ }^{9}$

The right side of table 1 presents the on-balance-sheet public spending due to the fiscal stimulus under this counterfactual. On-balance-sheet

7. These numbers are from Feng, Hu, and Moffitt's (2015) tabulations from the Urban Household Survey.

8. On the monetary policy side, the required reserve ratio was adjusted downward three times in the fourth quarter of 2008 , down from 17.5 to 16 percent and from 16.5 to 13.5 percent for large and small financial institutions, respectively. The official benchmark interest rates were cut four times in that period. The one-year deposit and loan rates, for instance, dropped from 4.14 percent and 7.2 percent to 2.25 percent and 5.31 percent, respectively.

9. We exclude the subitems in each category that should not be counted as investment. 


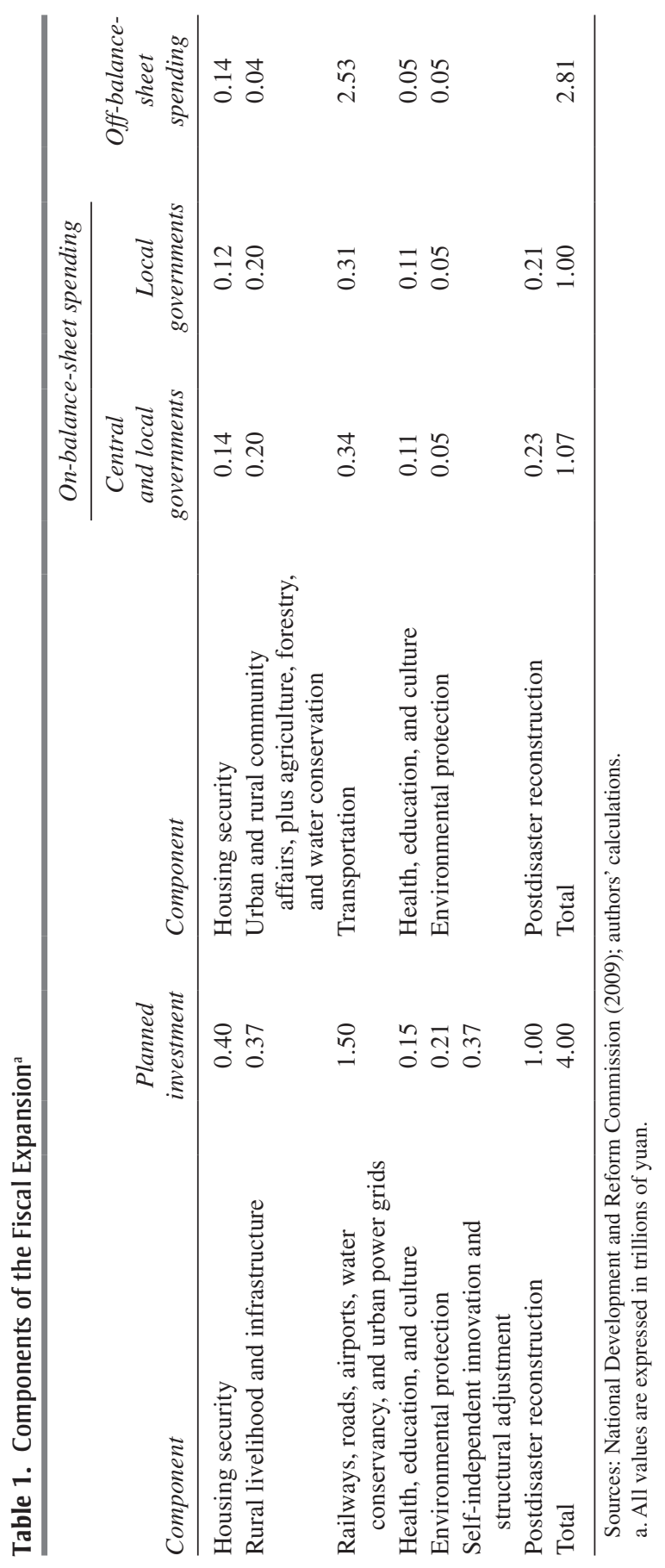


spending is shown for the consolidated governments (central and local), and just for the local governments. By comparing the former and latter columns, it can be seen that the additional spending due to the fiscal stimulus was mostly local government spending-there was very little additional spending by the central government. Furthermore, the magnitude of the on-balance-sheet spending is much smaller than the projected spending. The additional on-balance-sheet spending that we attribute to the fiscal stimulus is only slightly more than 1 trillion yuan, which is 3 trillion yuan short of the projected spending under the stimulus program. The discrepancy between the planned and on-balance-sheet spending is largest for "railways, roads, airports, water conservancy, and urban power grids" (1.5 trillion versus 0.34 trillion) and "postdisaster reconstruction" (after the Wenchuan earthquake).

Another way to see the discrepancy between planned and actual onbudget spending is to look at the budget deficit. Figure 1 shows that the combined budget deficit (by both local and central governments) increased from an average 1.4 percent of GDP in the 2000-08 period to 2 percent in 2009-10. If we assume that the budget deficit would have remained at 1.4 percent of GDP in the absence of the fiscal stimulus, then the onbalance-sheet spending due to the stimulus increased the budget deficit by 0.6 percent of annual GDP in 2009 and 2010. We remind the reader that the plan was to have stimulus spending equivalent to 11 percent of annual GDP in 2009 and 2010.

Although this evidence may suggest that the fiscal stimulus may not have been fully implemented, the evidence on aggregate investment from the national accounts indicates otherwise. The justification for looking at aggregate investment is that about 72 percent of the projected stimulus spending shown in table 1 should have been classified as investment in the national accounts. ${ }^{10}$ Figure 1 , which plots aggregate investment as a share of GDP, shows that the aggregate investment rate increased by roughly 5 percentage points in 2009 and 2010. Note that an increase of 5 percentage points in the investment rate in 2009 and 2010 is about 80 percent of 4 trillion yuan. This evidence is not conclusive, of course, because we do not know what the investment rate would have been in the absence of the stimulus program.

10. The 72 percent number assumes that spending on "rural livelihood and infrastructure" (0.37 trillion); "railways, roads, airports, water conservancy, and urban power grids" (1.5 trillion); and "postdisaster reconstruction" (1 trillion) are investment, whereas the other spending categories in table 1 are not. The sum of planned spending in the three "investment" categories is 2.87 trillion, which is roughly 72 percent of 4 trillion. 
Figure 4. Components of the Aggregate Investment Rate, 2005-14

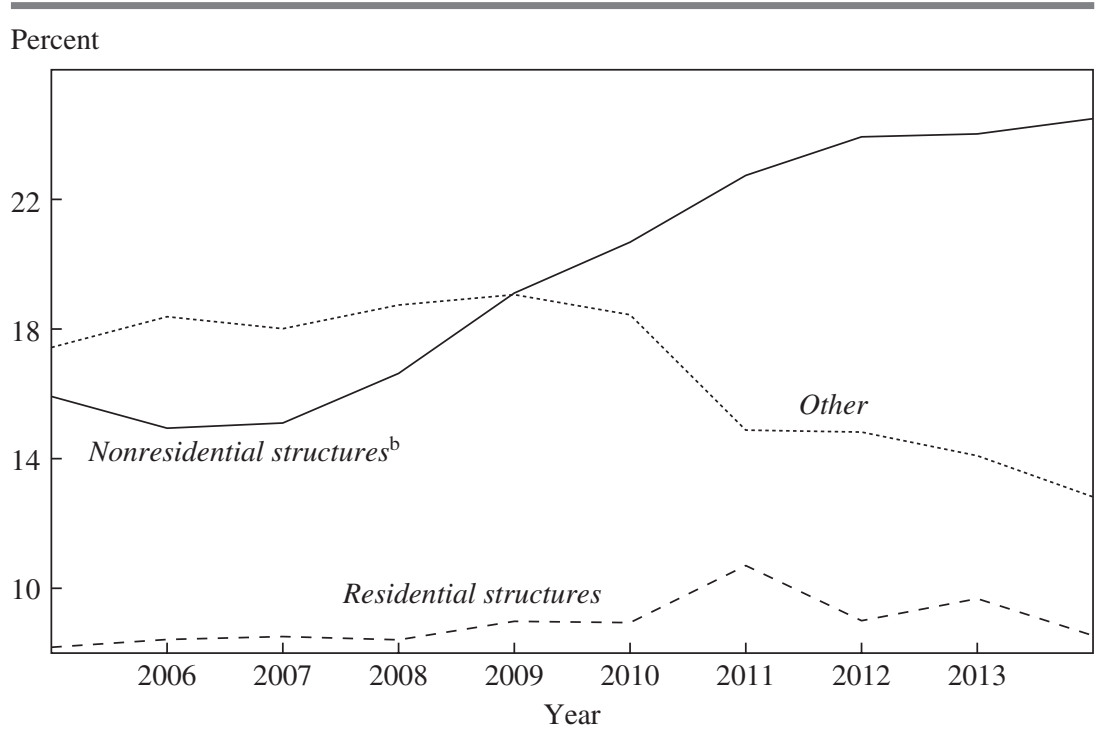

Source: National Bureau of Statistics of China.

a. The investment rate is the gross fixed capital formation series provided by the National Bureau of Statistics.

b. These include infrastructure and business structures.

Figure 4-which plots aggregate investment in infrastructure and nonresidential structures, housing, and other items (mostly machinery and equipment) as a share of GDP-provides another piece of evidence. ${ }^{11}$ Note that the investment rate in nonresidential structures includes public investment in infrastructure and private investment in nonresidential structures. (The Chinese national accounts do not provide separate data on public infrastructure spending and private spending on nonresidential structures.) Figure 4 shows that the investment rate in nonresidential structures increased from 16 percent of GDP in 2008 to 18 percent in 2009 and 20 percent in 2010 . There was no change in the investment rate in other items (mostly machinery and equipment), and there was a small increase in the investment rate in housing structures in 2009 and 2010. Remember that the stimulus program called for infrastructure spending equivalent to about 7.7 percent of GDP (72 percent of 4 trillion yuan) in 2009 and 2010. Assuming that the increase in the investment rate in nonresidential structures in 2009 and 2010 was only driven by

11. We measure investment in figures 1 and 4 by the annual gross fixed capital formation series provided by the National Bureau of Statistics. 
infrastructure investment, this suggests that more than three-quarters of the planned infrastructure spending in the stimulus program was finished by 2010 .

In summary, we do not know for sure whether the stimulus program was fully implemented. The increase in the aggregate investment rate by 5 percentage points of GDP in 2009 and 2010, as well as the increase in the investment rate in nonresidential structures in the same two years, suggests that it mostly was. Even so, only a quarter of the stimulus spending shows up on the government's balance sheet, and three-quarters of the spending was conducted by entities that were off the balance sheets of local governments. What exactly these off-balance-sheet entities are, and how much they matter, is what we turn to next.

\section{Financial Deregulation}

In the previous section, we showed that the stimulus program worth 4 trillion yuan only generated an increase in spending of 1 trillion yuan that appeared on the public sector's balance sheet in 2009 and 2010. Yet the evidence from the Chinese national accounts suggests that much more than 1 trillion yuan was actually spent. Because only a quarter of this spending showed up on local governments' balance sheets, the remaining threequarters must have been done by entities that were off these governments' balance sheets. In this section, we document the institutional changes that facilitated the growth of these off-balance-sheet institutions. In addition, we discuss the limited data available on the quantitative importance of this off-balance-sheet spending.

As we described above, local governments were prohibited from running budget deficits. However, in November 2008 the central government decided that local governments would be in charge of the stimulus program's spending. But how could this be done, given that the 1994 Budget Law and numerous regulations made it illegal for local governments to borrow? One possibility was that the central government could borrow on behalf of local governments and transfer the necessary funds to local governments, but this would obviously increase the central government's debt. Furthermore, any spending program for the central government had to be approved by the National People's Congress. Instead, the decision was made to circumvent the Budget Law by allowing local governments to use the off-balance-sheet companies known as LFVs, as described above. In this way, the debt would not show up on the central government's balance sheet, and there would be no technical violation of the Budget Law. 
In March 2009, the CBRC made this decision public (although the rules had already been informally relaxed before the public announcement):

Local governments will be encouraged to attract and to incentivize banking and financial institutions in order to increase their lending to the investment projects set up by the central government. This can be done in a variety of ways, including increasing local fiscal subsidies for interest payments, improving mechanisms for awarding loans, and establishing government investment and financing platforms that comply with regulations. (CBRC 2009)

Another important source of regulatory support, orchestrated by the central government, was the Ministry of Finance. Despite the existing regulations on the use of local government revenues and the Budget Law that prohibits local government from borrowing, the Ministry of Finance issued a regulation that allowed local governments to finance investment projects using all sources of funds, including budgetary revenues, land revenues, and funds borrowed by LFVs:

Local governments will be allowed to finance investment projects with essentially all sources of funds, including budgetary revenues, land revenues, and funds borrowed by local financing vehicles. (Ministry of Finance 2009)

The last regulatory change worth emphasizing is that local governments were encouraged to borrow from financial institutions, which was not allowed by the Budget Law and many regulations issued before 2008 . Although the new regulation says explicitly that external financing should only be used for investment projects set up by the central government, the loophole is that the new regulation does not apply to LFVs. By using these off-balance-sheet institutions, local governments can raise funds without violating the Budget Law.

There are two sources of publicly available information on the activities of these off-balance-sheet companies. First, LFVs that issue bonds must provide annual financial statements. However, those LFVs that do not issue bonds do not need to provide statements. These statements are compiled by a company called Wind. ${ }^{12}$ In addition to the identity of each LFV, the key data we use from the financial statements identify each LFV's total debt.

12. Wind defines a local financing vehicle as a company whose business covers "infrastructure and utilities" and whose major shareholder is a local government or a subsidiary of a local government. See online appendix table A2 for more details of the LFVs in the Wind database. The online appendixes for this and all other papers in this volume may be found at the Brookings Papers web page, www.brookings.edu/bpea, under "Past BPEA Editions." For more information about the Wind Economic Database, see http://www.wind.com.cn/ en/edb.html. 
There is, however, no information on the composition of LFVs' liabilities or assets.

The second source of information is from audits of all LFVs, including those that do not issue bonds, by the National Audit Office (NAO) of the People's Republic of China in 2011 and 2013. The reports of these audits include LFVs' total stock of debt in each year from 2006 to 2013. The reports also provide limited information on the composition of LFVs' liabilities and assets. The reports only present aggregated information; no individual data or decompositions for different types of LFVs are available.

There are two important differences between the data provided by Wind and by the NAO. First, the NAO's data cover all LFVs, whereas the Wind database only includes those LFVs that issue bonds. Second, the NAO's data only cover LFVs' "official" debt, which the NAO defines as "the debt that the government has the responsibility to repay or the debt to which the government would fulfill the responsibility of a guarantee or for bailout when the debtor encounters difficulty in repayment" (NAO 2011). Official debt is only a subset LFVs' total debt. This is because, although LFVs were originally set up to finance local infrastructure projects, many of them have since ventured into commercial projects. In contrast, the debt in the Wind database covers all LFV debt, including the debt used to finance the LFVs' commercial projects.

To illustrate the difference between the two measures of debt, it is useful to describe the activities of two LFVs with which we are familiar. The first is the Beijing Capital Group, which is owned by Beijing's local government. The Capital Group owns the Beijing subway, two toll highways (one from Beijing to Tianjin, and one from Beijing to Tongzhou), and a company that specializes in building urban roads and rain and sewage infrastructure. ${ }^{13}$ Only the debt used for these public infrastructure projects is classified as official local government debt by the NAO. The Capital Group also has three subsidiaries that are essentially real estate developers and another five that are financial service companies. ${ }^{14}$ Finally, the Capital Group's most recently established companies are in the green technology

13. Beijing Virescence Area Infrastructure Development and Construction is the subsidiary that specializes in urban roads and sewage. The Capital Group operates the Beijing subway and two highways through the Beijing MTR Corporation, the Tianjin Beijing-Tianjin Expressway, and the Beijing-Tongzhou Freeway.

14. The real estate companies are Bejing Capital Land, Capital Jingzhong (Tianjin) Investment, and Beijing Capital Investment and Development. The financial services companies are Capital Securities, Beijing Capital Investment \& Guarantee, Beijing Agricultural Investment, Beijing Agricultural Guarantee, and Beijing Capital Investment (a venture capital fund). 
Figure 5. The Number of Bond-Issuing Local Financing Vehicles, 2006-15

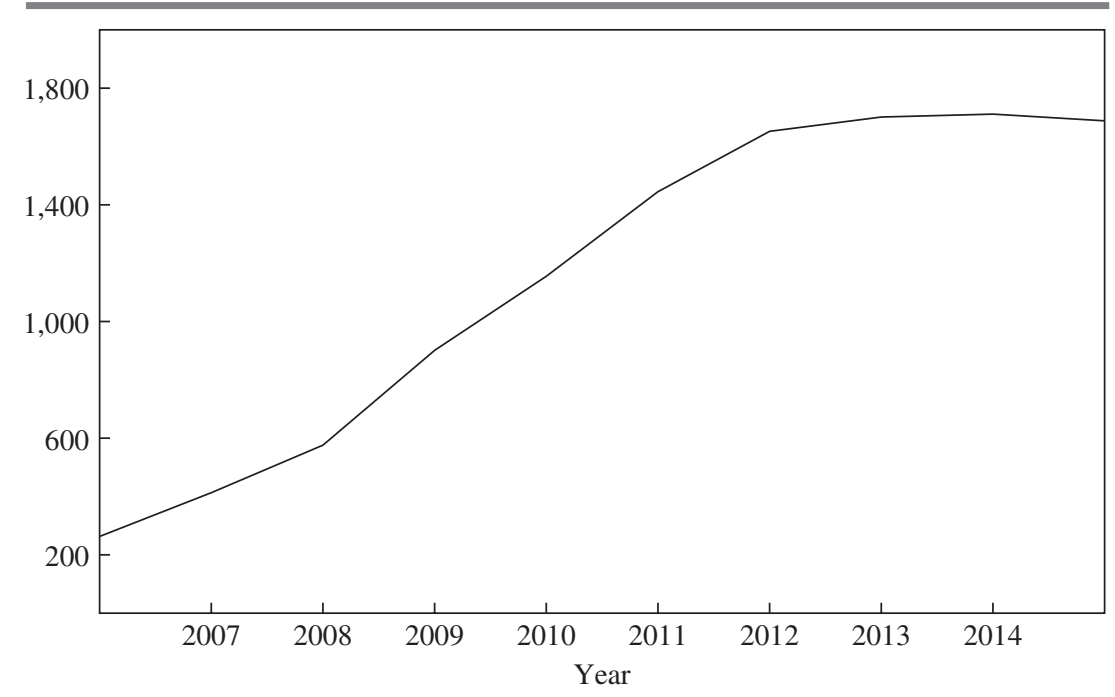

Source: Wind database.

and waste disposal businesses. For example, the Capital Group created Beijing Capital Waste Management NZ in 2014 in New Zealand and ECO Industrial Environmental Engineering in 2015 in Singapore, both of which are in the solid waste disposal industry. ${ }^{15}$

The second sample LFV is the Beijing State-Owned Assets Management Company (BSAM), which owns the main facilities built for the 2008 Beijing Olympics, including the National Stadium (Bird's Nest) and the National Aquatics Center (Water Cube). BSAM also has subsidiaries in the financial industry, in real estate development, and in manufacturing. For example, BSAM owns a large stake of the Bank of Beijing and the Beijing Automotive Group. The latter company is the primary investor in several car manufacturers, including a joint venture with Hyundai (Beijing Hyundai Motor). Only the debt used to build the sports facilities in Beijing should be counted as official debt, whereas the debt in the Wind database includes that incurred by all BSAM's subsidiaries.

Figure 5 plots the number of bond-issuing LFVs in the Wind database. As can be seen, there were only a small number of bond-issuing LFVs

15. The other recently established subsidiaries-Qinhuangdao Capital Star Light Technology and Beijing Capital Boom-Sound Science \& Technology—manufacture pollution control equipment. 
Figure 6. The Total Debt of Local Financing Vehicles, 2007-15

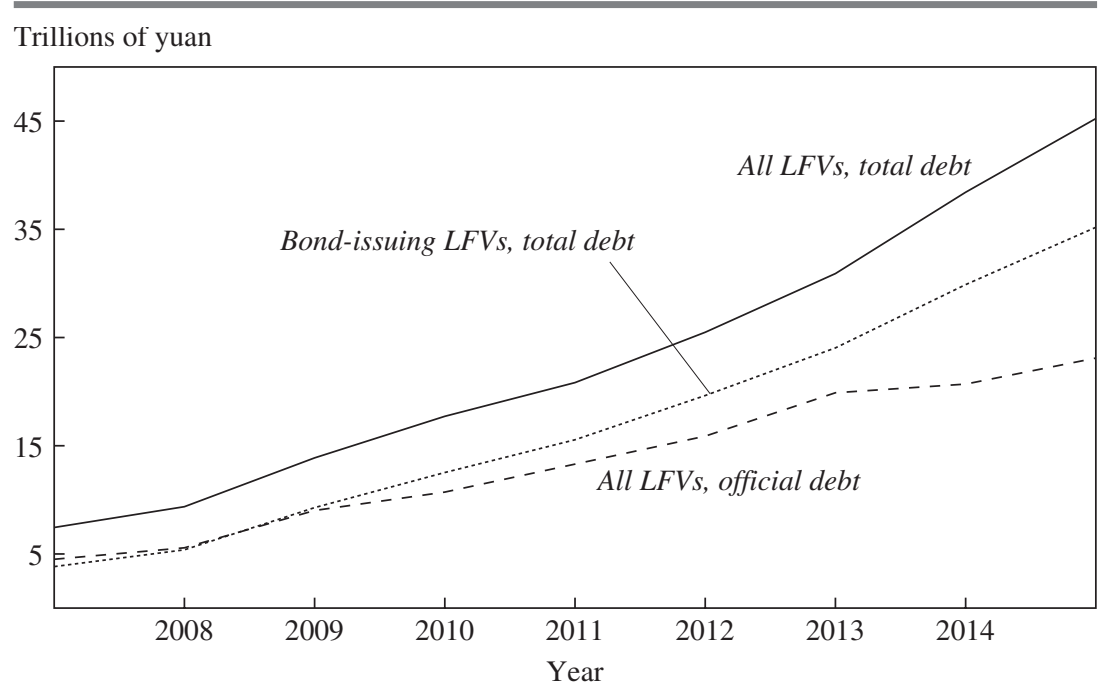

Sources: Authors' calculations; NAO (2011, 2013); Wind database.

before the fiscal stimulus. But after the controls over LFVs were lifted in early 2009 , the number of these off-balance-sheet companies soared, and had doubled by 2010 . The number of bond-issuing LFVs continued to grow after the end of the stimulus program, increasing from 1,200 in 2010 to about 1,700 by 2013 . We remind the reader that the data given in figure 5 only include those LFVs that issue bonds. According to the audit conducted by the NAO, there were 7,170 LFVs in June 2013. Of these, about 1,700 issued bonds, implying that about 5,400 LFVs were not in the Wind database that year.

Figure 6 presents the total debt of bond-issuing LFVs in the Wind database and the total official debt of all LFVs in the NAO's reports. ${ }^{16}$ There are limited data on official debt for all LFVs since 2013. In a press conference on May 26, 2016, Finance Minister Lou Jiwei said that the stock of local government debt stood at 16 trillion yuan at the end of 2015. But this number cited by Lou only refers to the debt that local governments are legally obliged to repay (this is called "direct

16. The NAO's 2013 report only gives the stock of debt at end of June 2013. We impute the stock of debt at the end of 2013 by doubling the change in stock from the end of 2012 to the end of June 2013. The debt in 2014 is set equal to the average of that in 2013 and 2015 . 
debt" in China). ${ }^{17}$ According to the NAO, the stock of direct debt was 10.9 trillion yuan in June 2013. The Ministry of Finance also said that the ratio of government debt to GDP would increase from 39.4 to 41.5 percent if the government were responsible for 20 percent of indirect debt. This implies indirect debt of 7.1 trillion yuan and total local government debt of 23.1 trillion yuan by the end of 2015 . This is the number we use in figure 6 for LFVs' total official debt.

Remember that the debt given in the NAO reports is only official debt, whereas the Wind database includes all the debt on the LFVs' balance sheets and not just the debt classified as official. Furthermore, the LFVs covered in the Wind database are only a subset of the LFVs included in the NAO's reports. The total debt, as reported in the Wind database, understates total debt because the smaller LFVs (5,400 LFVs in 2013) are not included in the Wind database. The debt described in the NAO's reports also understates total debt because it only counts official debt and omits the debt of the LFVs' commercial ventures. One way to see this last point is that although the NAO reports data from all LFVs, figure 6 shows that total debt as reported by the NAO is always smaller than the total debt of the much smaller sample of bond-issuing LFVs included in the Wind database.

The data provided by the NAO answer the question "How much LFV debt was used for local infrastructure projects?" Although this is an important question, we also want to know how the fiscal stimulus changed local governments' control over the allocation of resources. To answer this question, we need to know the accumulated debt used by LFVs for infrastructure and commercial projects. We have no data on the latter, but we can use the firm-level records of LFV data in the Wind database to impute the total LFV debt (official and commercial debt). Specifically, we assume that the true distribution of total LFV debt across different LFVs follows a Pareto distribution, and that the Wind data constitute a truncated sample of the true distribution. We then estimate the truncated Pareto distribution from the firm-level records in the Wind database and use this distribution's estimated parameters, along with the NAO's data on the total number of LFVs, to estimate the total stock of debt of those LFVs that are not in the Wind database. We estimate this "missing debt" separately for each year. ${ }^{18}$

17. The report of the IMF's (2016) Article IV consultation cites a figure that indicates that the government's debt as a share of GDP increased from an average of 15 to 16 percent of GDP in 2011-13 to 38.5 percent of GDP in 2014. This number is the "direct" debt and is close to the 39.4 percent for 2015 cited by Lou.

18. We provide the details of the imputation in the online appendix. 
Figure 7. Debt Accumulation by Local Financing Vehicles, 2007-15

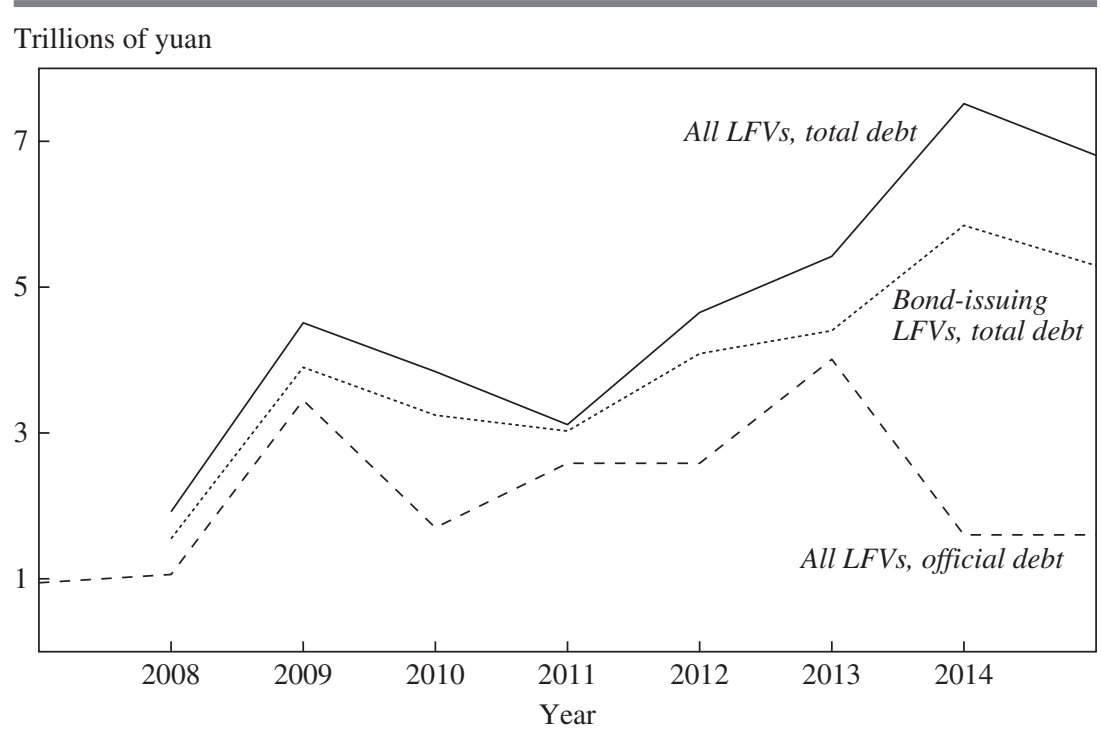

Sources: Authors' calculations; NAO $(2011,2013)$; Wind database.

a. Debt accumulation is defined as the change in debt for the calendar year.

Figure 6 presents the "true" stock of LFV debt imputed via this method (the solid line). The gap between this number and the official debt reported by the NAO (the dashed line) is the stock of debt of the LFVs' commercial subsidiaries. The difference in 2015 is very large—official debt stood at 23 trillion yuan, but our estimate of LFVs' true debt is about 45 trillion yuan. In turn, the gap between the true stock of LFV debt and the debt in the Wind data is simply due to the fact that the Wind data do not include the large number of small LFVs.

Figure 7 presents the change in the debt for each year implied by the stock of debt shown in figure 6 . The change in the debt reported by the NAO represents LFVs' spending on official projects, most of which are infrastructure projects. For example, LFVs' official borrowing increases from 1 trillion yuan in 2008 to an average of 2.5 trillion yuan in 2009 and 2010. The bulk of official LFVs' borrowing in these two years was likely for spending under the stimulus program. Specifically, assuming that the stock of off-balance-sheet debt would have remained constant as a share of GDP in the absence of the stimulus program, local governments borrowed an additional 3.6 trillion yuan in 2009 and 2010 through off-balance-sheet entities. When we add 3.6 trillion yuan in off-balance-sheet spending to the 
1 trillion yuan in on-balance-sheet spending calculated above, we find that the stimulus generated an additional 4.6 trillion yuan in spending. Remember that the stimulus program called for 4 trillion yuan in spending.

Figures 6 and 7 also clearly show that off-balance-sheet spending by local governments did not return to prestimulus levels after the stimulus program ended in 2010. This is true whether one looks at the accumulation of official debt or the total accumulation of debt we impute. Debt accumulation for infrastructure projects decreased after 2013. However, this decline was more than offset by LFVs' unofficial debt accumulation. Our estimates are that LFVs' debt increased by 14.6 trillion yuan in 2014 and 2015. Put differently, LFVs' total spending in 2014 and 2015 was more than three times larger than the amount spent on the fiscal stimulus in 2009 and 2010. In contrast, official local government debt increased by 3.2 trillion yuan in the same period. If local infrastructure investment projects were only financed by official local government debt, off-balance-sheet spending by local governments would have resulted in spending on local infrastructure roughly equivalent to 2.4 percent of GDP in 2014 and 2015. The gap between the accumulation of official local government debt and our estimates of the total change in off-balance-sheet debt suggests that 8.6 percent of GDP was spent by local governments in 2014 and 2015 on what were essentially private commercial projects.

We have limited information on the composition of LFVs' liabilities. The earliest information is from a speech given in 2009 by the CBRC's president, who said that in 2009 banks loaned 3.05 trillion yuan to LFVs. We assume that this number refers to bank loans for official LFV debt, although we are not sure. According to the data from the NAO plotted in figure 7, LFV debt increased by about 3.4 trillion yuan in 2009. Putting these two numbers together, we find that 90 percent of local governments' off-balance-sheet spending in 2009 was funded by bank loans. The NAO provides a more complete breakdown of the funding sources for LFVs' outstanding official debt as of June 2013. These data indicate that 56.6 percent of the liabilities making up official LFV debt consisted of bank loans, 10.3 percent of bonds, and 11.6 percent of loans from trust companies. This information suggests that during the fiscal stimulus program, LFVs' liabilities were predominantly bank loans but since then have shifted away from bank loans.

Turning to the composition of LFVs' assets, the NAO also provides information on how official debt has been used; this is presented in table 2 . One should interpret these numbers with caution, as it is not clear how carefully this information was audited. With this caveat in mind, the numbers 
Table 2. Local Governments' Cumulative Off-Balance-Sheet Expenditures as of June 2013

\begin{tabular}{lc} 
Type of expenditure & $\begin{array}{c}\text { Percent of total } \\
\text { expenditures }\end{array}$ \\
\hline Municipal construction & 34.6 \\
Transportation infrastructure & 24.4 \\
Land storage & 11.2 \\
Housing security & 6.5 \\
Health, education, and culture & 5.8 \\
Agriculture, forestry, and water conservation & 3.2 \\
Environmental protection & 2.7 \\
Industry and energy & 1.4 \\
\hline
\end{tabular}

Source: NAO (2013).

in the audit report indicate that about 60 percent of local governments' off-balance-sheet expenditures went to infrastructure (including municipal construction and transportation infrastructure).

This information also allows us to provide one more check on whether the 4 trillion yuan stimulus program was carried out. We do not know what the official debt raised in 2009 and 2010 was spent on, but we know that the additional official off-balance-sheet debt in these two years totaled 3.6 trillion yuan. If we assume that the share of the debt raised in 2009 and 2010 spent on each item is the same as given in table 2, then we can estimate the official off-balance-sheet expenditures of local governments during the fiscal stimulus program in 2009 and 2010. This information is summarized in the last column of table 1 . The comparison of spending categories in the NAO report and in the project documents of the fiscal stimulus is not perfect. For example, it is not clear how exactly expenditures for "postdisaster reconstruction" are classified by the NAO. Nonetheless, when we add the on-balance-sheet and off-balance-sheet expenditures, we get the consistent story that about 60 percent of the stimulus was spent on infrastructure projects (broadly defined).

Table 3 provides more evidence that local governments have used LFVs since 2010 to circumvent budget constraints. We exploit the cross-sectional variation across localities in the tightness of the official budget constraint and examine whether localities with tighter official budget constraints make more use of LFVs. In the prestimulus period, when LFVs were heavily regulated, we expect to see no correlation between LFVs' borrowing and the local fiscal gap. In contrast, the relaxation of the constraints on off-balance-sheet borrowing had led to a positive correlation since 2009. The first column of table 3 reports the benchmark fixed-effect regression 
Table 3. Fixed-Effects Regressions on Local Financing Vehicles' Debt Growth ${ }^{\mathrm{a}}$

\begin{tabular}{lcccc}
\hline & \multicolumn{4}{c}{ Log of debt } \\
\cline { 2 - 5 } & $(1)$ & $(2)$ & $(3)$ & $(4)$ \\
\hline One-year lagged log of & 0.492 & 0.488 & 0.467 & 0.464 \\
$\quad$ LFV debt & $(0.011)$ & $(0.011)$ & $(0.013)$ & $(0.013)$ \\
Fiscal gap & 0.867 & -1.538 & 1.099 & -1.083 \\
& $(0.308)$ & $(0.514)$ & $(0.360)$ & $(0.563)$ \\
Fiscal gap $\times$ post-2009 & & 2.355 & & 2.097 \\
& & $(0.404)$ & & $(0.417)$ \\
Year dummies & Yes & Yes & Yes & Yes \\
Other controls & No & No & Yes & Yes \\
No. of observations & 4,476 & 4,476 & 3,855 & 3,855 \\
$R^{2}$ & 0.778 & 0.780 & 0.753 & 0.755 \\
No. of issuers & 877 & 877 & 861 & 861 \\
\hline
\end{tabular}

Source: Authors' calculations.

a. Standard errors are in parentheses. Observations are for city-level local financing vehicles.

b. The fiscal gap is defined as (local fiscal expenditures - local fiscal revenue)/local GDP.

c. Other controls include log of GDP, log of population, and log of GDP growth.

between the log of total debt from LFVs in a locality and the local fiscal gap (measured as the official budget deficit as a share of local GDP). In the second column, we add an interaction term between the fiscal gap and a post-2009 dummy that equals 1 for the years since 2009 and 0 otherwise. The interaction term is positive and highly significant. In other words, an LFV's faster debt growth is associated with a widening of the local fiscal gap only in the poststimulus period. In the third and fourth columns, we add a set of controls-including the logs of GDP, population, and GDP growth-but find little change in the results.

Since the end of the stimulus program, the central government has made numerous attempts to roll back these off-balance-sheet financial institutions, but thus far with little success. The first attempt came in November 2009, when the Ministry of Finance issued a document that prohibits local governments from providing loan guarantees and warned local governments against undertaking more spending on infrastructure than is stipulated by the stimulus program. The first formal regulation seeking to restrict off-balance-sheet spending by local governments came from the State Council in June 2010. This regulation issued new rules that required local governments to seek approval for new investment projects. According to the rules, banks also had to strictly enforce the minimum share of capital that local governments had to invest in projects funded via the LFVs.

In response, local governments found new ways to raise funds for their off-balance-sheet spending. Since the State Council issued new rules in 
June 2010, the most common method used by local governments to skirt the minimum capital requirements has been to transfer ownership of land to the LFVs. The off-balance-sheet companies can then use the land as collateral to borrow from banks, and in this manner they circumvent the need to meet the capital requirements stipulated by the new rules. Another method has been to borrow from less-regulated trusts. As discussed below, loans from trusts accounted for 8 percent of all LFV debt by June 2013. Another common method has been to use build-transfer arrangements, whereby a private company gets a concession from a local government in exchange for a share of the project's revenues.

The central government has attempted to limit local governments' ability to obtain new funds via their LFVs through these alternative channels. For example, in December 2012 four agencies of the central government-the Ministry of Finance, the National Development and Reform Commission, the People's Bank of China, and the CBRC_-jointly issued a decree to limit borrowing by LFVs. The most recent attempt by the central government to stop off-budget borrowing by local governments came in August 2014, when the 1994 Budget Law was amended to allow provincial governments to issue bonds, subject to quotas set by the State Council. ${ }^{19}$ However, there are three important restrictions on the borrowing that local governments can undertake under the August 2014 Budget Law. First, an annual bond issue cannot exceed the quota set by the State Council and approved by the National People's Congress. Second, an annual bond issue must be part of the budget proposed by the provincial government and approved by the provincial people's assemblies, and needs to include a plan for the repaying the debt. And third, the bond issue can only be used for public capital expenditures, not for recurring expenditures.

At the same time, the new Budget Law prohibits local governments and their branches from borrowing in any other form, and, unless otherwise specified by law, from offering any credit guarantee to any organization or individual. In September 2014, the State Council issued document number 43 to make these rules explicit (State Council 2014). This document states that an LFV does not have the authorization to borrow on behalf of a local government. If the only business of an LFV is to borrow on behalf of the government, it should be shut down. If the LFV provides public services, the document stipulates that the local government needs

19. More precisely Article 35 of the new Budget Law passed in August 2014 allows provincial-level governments to issue bonds. Guangdong, Shanghai, and Zhejiang have been allowed to issue local government bonds since 2011. 
to provide prespecified compensation to cover the cost not covered by the fees the LFV charges for the services. The document states that financial institutions cannot provide credit to local governments or request credit guarantees from local governments. The goal, which Chinese policymakers labeled a "dredging and blocking" strategy, was to entirely eliminate LFVs by replacing LFVs' debt with local government bonds within three years.

Our limited evidence suggests that debt accumulation backed up by the local government declined in 2014 and 2015 (see figures 6 and 7). However, as we have discussed, debt accumulation by LFVs for their commercial ventures increased in 2014 and 2015. Published reports of the government's debt show that public debt as a share of GDP increased from an average of 15 to 16 percent from 2011 through 2013 to 38.5 percent in 2014. This increase in public debt reflects the recognition of "direct" debt incurred by off-balance-sheet companies on behalf of local governments. However, the amount of direct LFV debt swapped (as of the writing of this paper) for local government bonds is only 3.2 trillion yuan (Ministry of Finance 2016), which is much smaller than the approximately 22 percent of GDP suggested by the increase in public debt numbers. ${ }^{20}$

The reason for this discrepancy is that less than one year after the new rules were issued, the central government showed signs of backing off from its crackdown on LFVs. Perhaps in response to the small decline in the investment rate in 2014, and more generally the slowdown in aggregate growth (see figures 1 and 2), in May 2015 the State Council issued a new decree (document 40) that reversed its attempts to crack down on LFV borrowing (State Council 2015). In fact, this decree urged financial institutions to continue to lend to LFVs.

We do not yet have data on investment spending since 2014, but the National Bureau of Statistics of China (NBS) provides a monthly series on fixed-asset investments that provides more recent information. Furthermore, in 2015, for the first time the NBS released monthly data on fixedasset investments in infrastructure. But this fixed-asset investment series has two problems. First, it includes purchases of land and preexisting structures, as well as expenditures on previously used machinery. Second, it is

20. We do not know exactly how the debt swap would affect the total outstanding debt of LFVs, but it is likely that the swap reduced the debt of the LFVs in the Wind database. Adding the 3.2 trillion yuan back would increase our estimated total debt of LFVs to 48 trillion yuan by the end of 2015 . 
based on a survey of large investment projects, which may not be representative of all investment spending. The gross fixed-capital formation series we use in figures 1 and 4 solves these two problems, but is only available at an annual frequency (and is only available until 2014 at the time of the writing of this paper). With this caveat in mind, infrastructure investment measured by fixed-asset investments grew at an annual rate of 17.2 percent in 2015, which is higher than the rate of aggregate investment of 10 percent. In the first seven months in 2016, fixed-asset investments in infrastructure grew at an annual rate of 19.6 percent, 2.4 times higher than the growth rate of aggregate fixed-asset investments.

In sum, although the central government has made several attempts to curb LFVs during the past five years, the most recent evidence suggests that the central government is once again resorting to the same methods it used in 2009 and 2010. We do not know what will happen in the future, but the next section turns to an assessment of the aggregate effects of the off-balance-sheet spending undertaken by local governments from the end of the fiscal stimulus in 2010 to 2016.

\section{The Aggregate Effects of the Partial Financial Liberalization}

We now turn to an assessment of the aggregate effects of the partial financial liberalization. A common argument is that the main effect of the offbalance-sheet spending by local governments, primarily on infrastructure investment, is to crowd out investment by private firms. Yi Huang, Marco Pagano, and Ugo Panizza (2016), for example, provide empirical evidence that the investment rate of private industrial firms in localities with large increases in off-balance-sheet spending is lower than the investment rate of similar firms in localities that accumulated less debt.

This could be true, but note that the aggregate investment rate, which includes investment by private firms and spending by LFVs, has increased by 5 percentage points since 2008. How can the investment rate increase by so much? Figure 8 shows that there was no corresponding increase in the savings rate. If anything, there has been a small decline in the savings rate. The adjustment instead has been entirely on the external balance. China's current account shifted from a surplus of about 10 percent of GDP in 2008 to 2 to 3 percent of GDP by 2013 and 2014.

Another way to see this is to look at the asset composition of China's banking system (primarily formal banks and trusts). Ideally, we would directly measure the shares of loans to private firms and of loans to LFVs in the total assets of the banking system. The published balance sheets of the 
Figure 8. Aggregate Investment, Savings, and Current Account Surpluses, 2005-14

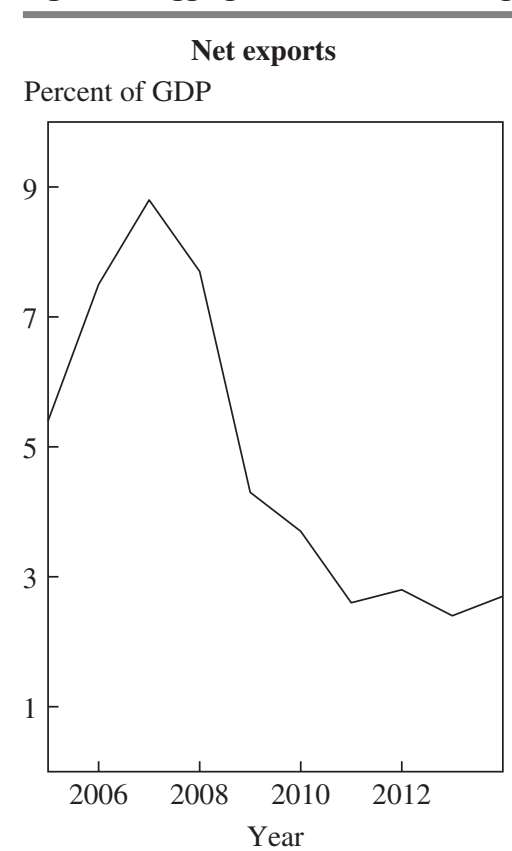

Aggregate investment and saving Percent of GDP

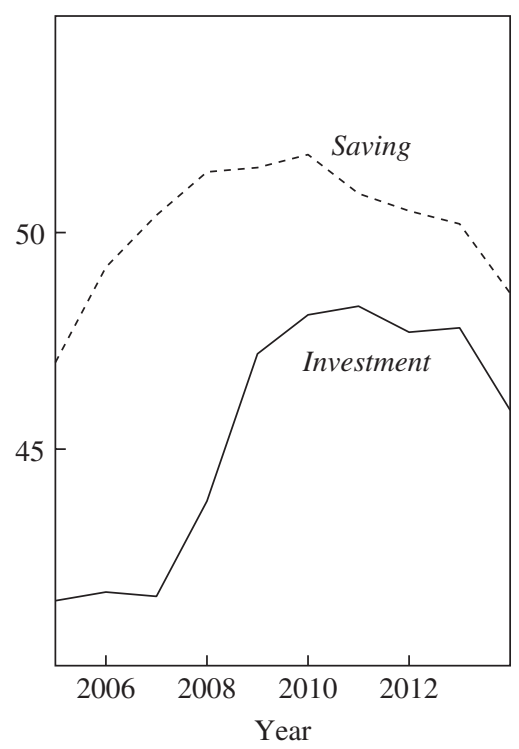

Source: China Statistical Yearbook.

Chinese banking system do not provide this information, but we can use our estimate of total loans from banks and trusts to LFVs to impute this number. The top panel of figure 9 presents the share of loans from the banking system to LFVs as a share of the system's total assets, where total assets consist of reserve assets, government and central government bonds, and loans to nonfinancial institutions. (We provide more detail on how we estimate the asset composition of the financial system in the online appendix.) The line labeled "local government debt" measures loans from the banking system to LFVs used for infrastructure projects (official debt), whereas the line labeled "debt of all LFVs" is our estimate of all the financial system's loans to the LFVs (not just for LFVs' official debt). This number uses our estimate of bank and trust loans to LFVs,along with published data on the banking system's total assets. Not surprisingly, official LFV debt as a share of total assets has increased since 2008. Furthermore, as one would expect from figure 6, total banking system loans to LFVs have increased even more, reflecting the system's loans to fund LFVs' commercial activities. 
Figure 9. Composition of Assets of China's Banking Sector, 2008-14

\section{Lending to local governments}

\section{Percent}

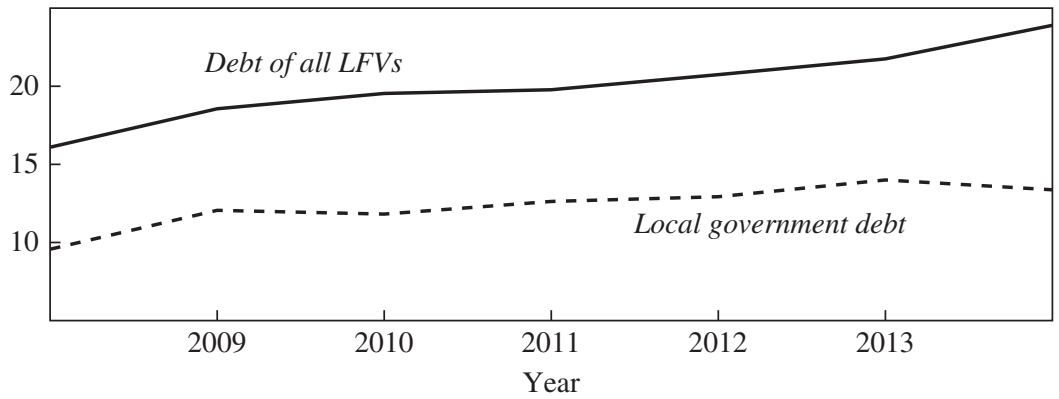

\section{Corporate and household liabilities ${ }^{b}$}

Percent

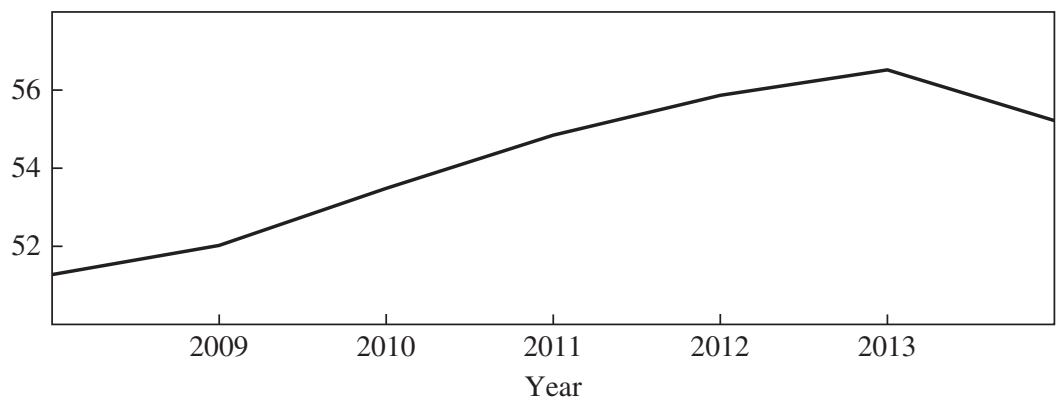

\section{Bonds and reserves}

Percent

Percent

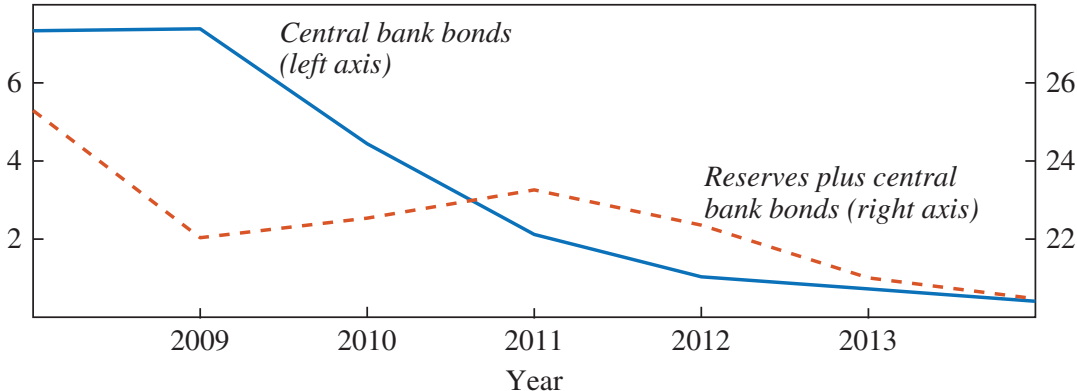

Sources: People's Bank of China; China Statistical Yearbook; National Bureau of Statistics of China; Wind database.

a. The banking sector includes both formal and shadow banking. Banking assets consist of reserve assets, government and central government bonds, and loans to nonfinancial institutions. For details, see the text and the online appendix.

b. Corporate liabilities exclude local financing vehicles. 
Despite the increase in lending to LFVs, the middle panel of figure 9 shows that between 2008 and 2014, the debt of nonfinancial institutions (excluding LFVs) as a share of financial institutions' total assets increased by 4 percentage points. How can the banking system lend more (as a share of total assets) to LFVs and at the same time also lend more to nonfinancial institutions? The figure's bottom panel provides the answer. It shows that the banking system's holdings of central bank bonds fell by about 7 percentage points (as a share of total banking system assets) during the same period. Moreover, the share of reserves and central government bonds drops by 4.5 percentage points. This is about 3.5 percentage points more than the increase in the debt of all LFVs as a share of total assets. This fact suggests that increasing the share of local government debt on the banking system's balance sheet was more than offset by the declining share of central bank bonds, reserves, and government bonds. Put differently, the investment that is crowded out by the LFVs' spending is primarily the central bank's purchases of U.S. Treasury bills, and loans to firms have increased as a share of the financial system's assets. Viewed through the lenses of the decline in China's current account surplus, the other side of the decline in the central bank's bond holdings in the banking system is that the rate at which the central bank has been sterilizing the banking system's purchases of central bank bonds on the money supply has declined since 2008. ${ }^{21}$

Finally, we can also directly measure the investment rate of private versus state-owned firms. We do not have this information for the aggregate economy, but we can measure this using the firm-level data from the Chinese Industrial Survey. We plot this in figure 10. Not surprisingly, the investment rate of state-owned firms exceeds that of private firms in the industrial sector, reflecting the well-documented preferential access of state-owned firms to credit. Here, the investment rate of private industrial firms declines from an average of 15 percent in the years 2006-07 to an average of 12 or 13 percent in 2011-12. However, it is less clear whether this small decline reflects the crowding-out effect of LFVs' spending, given that the investment rate of state-owned industrial firms fell by even more over this period.

Therefore, if aggregate private domestic investment has not suffered from LFVs' growth, what are the main effects of local governments' offbalance-sheet spending? Here, it is useful to sketch a toy model, to make two points. First, partial financial liberalization-which is what happened

21. For institutional details and theoretical analyses of China's sterilization, see Song, Storesletten, and Zilibotti (2014) and Chang, Liu, and Spiegel (2015). 
Figure 10. Investment Rate by Ownership in the Industrial Sector, 2005-12

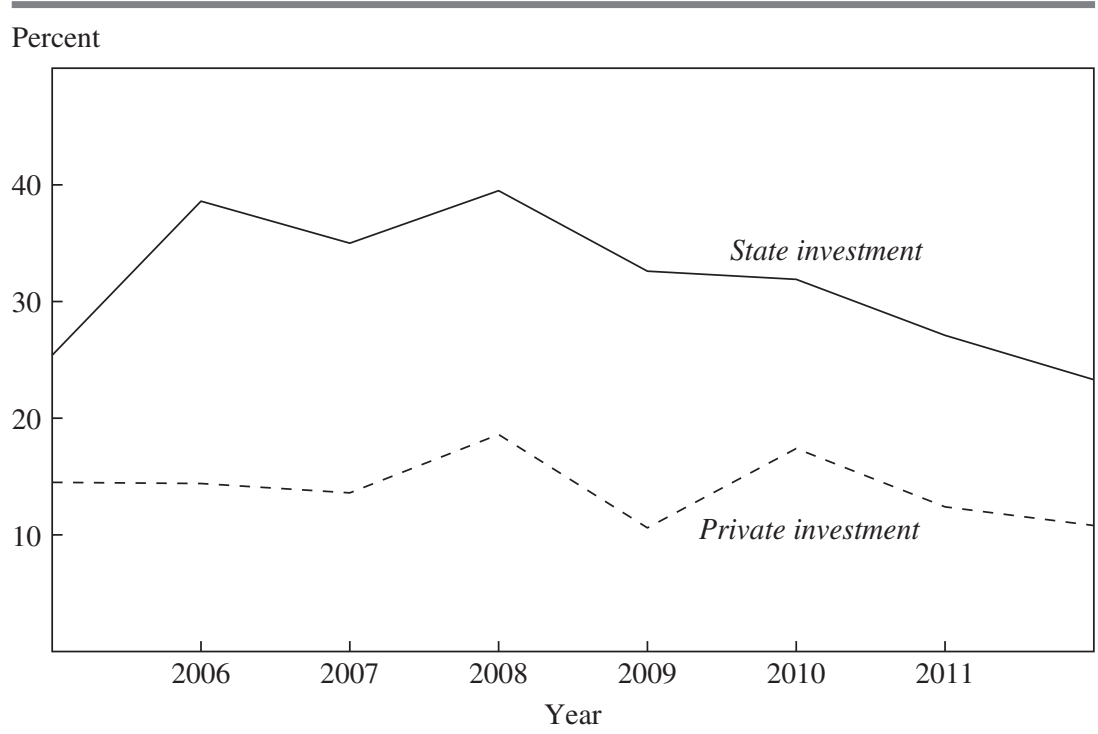

Source: China Statistical Yearbook.

in China-may worsen the allocation of resources. And second, the model also helps us understand why the boost in aggregate investment driven by financial liberalization will necessarily reduce the trade surplus.

The economy consists of a financial intermediary and two types of firms - connected and unconnected. There is no heterogeneity within each type. All firms produce a homogeneous good with this production technology: $Y_{i}=A_{i} K_{i}^{\alpha}$, where $Y_{i}$ is output, $i \in\{c, u\}$, and where $c$ and $u$ respectively represent connected and unconnected firms. Here, we consider $K_{i}$ to be capital a firm needs to borrow from the financial intermediary.

The representative connected firm can borrow from the financial intermediary at a regulated interest rate, denoted by $\bar{r}$, subject to a borrowing limit $\bar{K}$. Zheng Song, Kjetil Storesletten, and Fabrizio Zilibotti (2011) define $\bar{K}=\infty$. For simplicity, we assume $\bar{K}$ to be a policy parameter that is exogenous to the connected firm. There is also a market interest rate, denoted by $r$, at which both connected and unconnected firms can borrow. We maintain the following assumption throughout: $\bar{r}<\alpha A_{c} \bar{K}^{\alpha-1}<r$. The first inequality guarantees that the connected firm will always borrow up to the limit $\bar{K}$ at the regulated interest rate. The second inequality, conversely, rules out the possibility that the connected firm will borrow from 
the market. The representative unconnected firm can only borrow at the market interest rate, $r$, which is equal to the marginal product of capital: $r=\alpha A_{u} K_{u}^{\alpha-1}$.

The financial intermediary can both borrow from and lend to the world market at an exogenous interest rate of $r^{*}$. The financial intermediary also takes domestic savings at a regulated deposit rate. For simplicity, we let the regulated deposit rate equal $r^{*}$. Aggregate domestic deposits, denoted by $D$, are assumed to be exogenous. The economy has a trade surplus if the aggregate fund demand, denoted by $K$, is smaller than aggregate domestic savings:

$$
\text { Surplus }=D-K=D-\left(K_{c}+K_{u}\right) .
$$

The trade surplus shows up as foreign assets on the financial intermediary's balance sheet. Thus, the above equation can be rewritten as the balancesheet constraint

$$
D=\bar{K}+K_{u}+F,
$$

where $F$ denotes foreign assets.

Finally, we introduce a quadratic lending cost for the financial intermediary. The intermediary's profits are

$$
\pi=r \bar{K}+r K_{u}+r^{*} F-r^{*} D-\frac{\gamma}{2}\left(\bar{K}+K_{u}\right)^{2},
$$

where $\gamma$ is a parameter affecting the marginal lending cost. The first and second items in the profit function are profits of lending to the connected and unconnected firms, respectively. Maximizing the profits, subject to the balance-sheet constraint, gives this first-order condition:

$$
\alpha A_{u} K_{u}^{\alpha-1}=r^{*}+\gamma\left(\bar{K}+K_{u}\right),
$$

where we substitute the first-order condition for the unconnected firm for $r$.

There are two immediate results. First, a financial liberalization for the connected firm that increases its borrowing limit $\bar{K}$ will crowd out funds allocated to the unconnected firm by increasing the marginal lending cost $(\gamma>0)$. This financial liberalization will lower the marginal product of capital among connected firms and raise the marginal product of capital among unconnected firms. Second, differentiating the equation given above with respect to $\bar{K}$ shows that $\left|d K_{u} / d \bar{K}\right|<1$. That is to say, the financial liberalization 
Figure 11. Firms' Debt-Revenue Ratios, 1998-2015

\section{All firms}

Ratio of debt to revenue

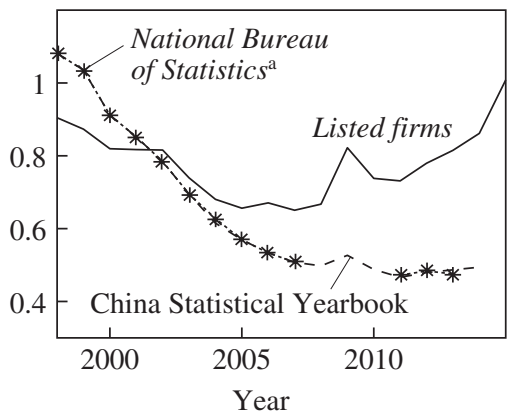

State-owned manufacturing firms

Ratio of debt to revenue

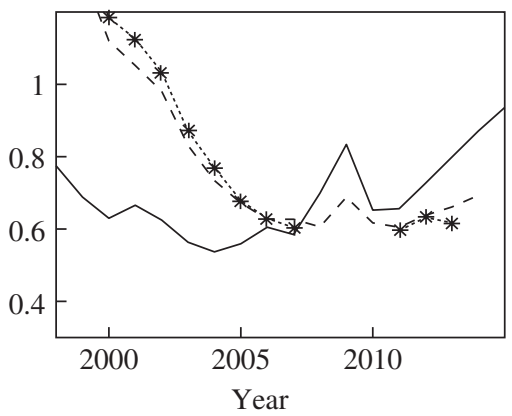

All manufacturing firms

Ratio of debt to revenue

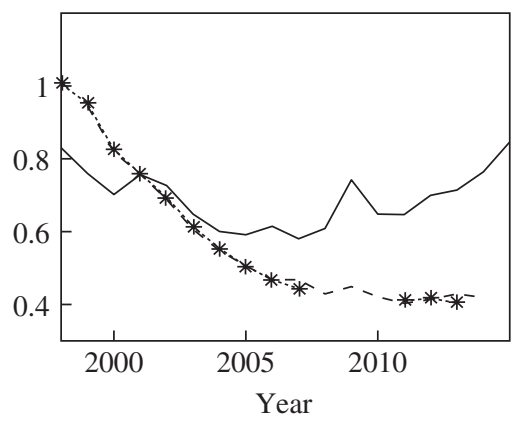

Private manufacturing firms

Ratio of debt to revenue

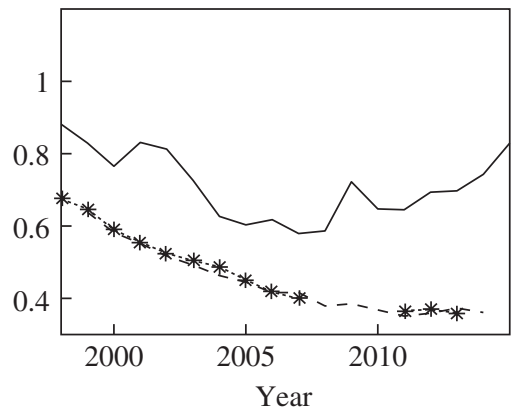

Sources: China Stock Market and Accounting Research database; China Statistical Yearbook; National Bureau of Statistics of China.

a. Data are from the Annual Survey of Industrial Firms, with years missing for 2008-10.

will always increase the aggregate fund demand and, hence, reduce fund inflow or trade surplus.

With this model in mind, we now turn to the patterns in the data. We first examine the allocation of capital between listed industrial firms and all industrial firms. As we discuss in Bai, Hsieh, and Song (2016), the favored firms are almost always the largest firms in a locality. The data on all firms are from the microeconomic records of the Chinese Industrial Survey, which is conducted by the NBS. ${ }^{22}$ The solid line in the top left panel of figure 11 plots the debt-revenue ratio for all the listed firms. This ratio

22. The sample consists of all state-owned industrial firms and private industrial firms with revenue above 5 million yuan before 2007 and 20 million yuan after 2010 . 
exhibits a downward trend before 2009, falling from 0.90 in 1998 to 0.67 in 2008, indicating that the listed firms were becoming less dependent on debt financing. The year 2009 stands out as a turning point. The ratio of debt to revenue jumps to 0.82 , with revenue roughly unchanged and debt up by 33.9 percent, or 2.3 trillion yuan. In sharp contrast, NBS firms show a smaller increase in their debt-revenue ratio, up from 0.50 in 2008 to 0.53 in 2009 (the dashed line in the figure's top left panel). In other words, we find a highly asymmetrical expansion of debt between listed and NBS firms. The stimulus program-including its monetary expansionary policies, the effort to invest 4 trillion yuan, and the associated financial deregulationseems to favor listed firms vis-à-vis debt financing.

The more interesting finding is that after scaling their debt-revenue ratio back a bit in the years 2010-11, listed firms continued to expand their debt at a much faster rate relative to their revenue. In 2015, the debt-revenue ratio reached 1, more than doubling the ratio of NBS firms in 2014. The divergence of the debt-revenue ratio between listed and NBS firms after 2011 is hard to explain due to discrimination embedded in the stimulus program. Rather, we view it as evidence supporting our story that financial deregulation opens up a new channel through which financial resources can be directed toward the connected firms.

We next conduct several checks for robustness. Listed firms cover all industries, whereas NBS firms are all from the industrial sector. To control for industry heterogeneity, the top right panel of figure 11 only uses manufacturing firms. The results are essentially the same. The figure's bottom left and right panels distinguish state-owned and private manufacturing firms. As expected, in 2009 the jump of the debt-revenue ratio for stateowned listed firms is more dramatic than their private counterparts. The divergence of the debt-revenue ratio is more pronounced between private listed firms and private NBS firms. Using firm-level data (dotted lines) yields almost the same results as those from aggregate data in the China Statistical Yearbook.

Another way to examine the efficiency of capital allocation is to directly measure the dispersion of the marginal product of capital across firms. We do not directly measure the marginal product, but with some assumptions, we can proxy the marginal product of capital with the average product of capital. Given this assumption, the overall dispersion in the marginal product of capital can be measured by the dispersion in the average product of capital. Figure 12 plots the variance in the log of the average product of capital (value added relative to the capital stock) across privately owned industrial firms from 1998 to 2012 (we do not have firm-level data from 
Figure 12. Dispersion in the Average Product of Capital across Privately Owned Industrial Firms, 1998-2013

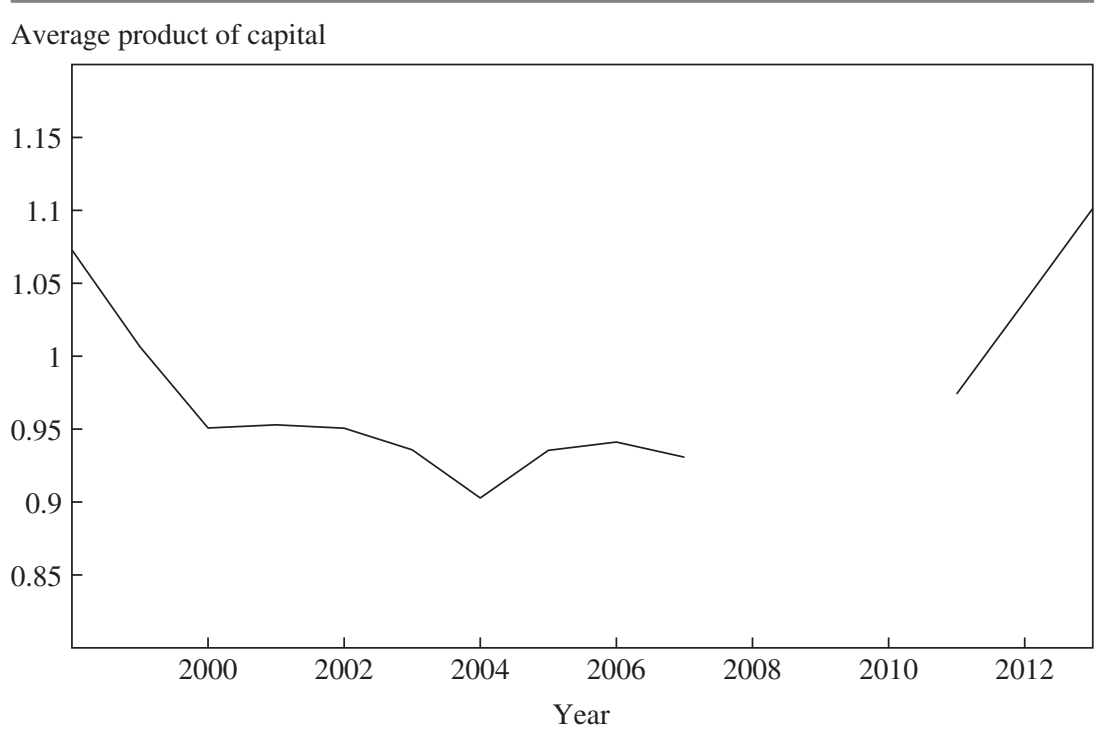

Sources: National Bureau of Statistics of China; authors' calculations.

a. This figure plots the variance of the log of the ratio of value added to fixed capital among private firms in the balanced panel of industrial firms. The ratio of value added to fixed capital is divided by the median value in each four-digit industry. The top and bottom 1 percentiles in each industry in each year are dropped.

2008 to 2010). We normalize the average product of capital for each firm by the median average product in each three-digit industry, and we also trim the 1 percent outliers in each industry-year.

As can be seen, the dispersion in the average product of capital falls slightly from 1998 to 2007, but shows a sharp increase between 2011 and 2013. Remember, this is exactly when off-balance-sheet spending by local governments took off and when we start to see a larger amount of LFV debt used to fund commercial activities. To be clear, the dispersion in the average product of capital can reflect forces other than differences in access to capital across firms. For example, adjustment costs or differences in markups across firms will also show up as differences across firms in the average product of capital (Song and Wu 2015). However, there is no reason why these forces should change over time. Growing misallocation of capital would lower aggregate total factor productivity and output growth; and, as figure 2 shows, the growth rate of aggregate GDP did fall after 2008.

The forces behind the growth slowdown in China are clearly complex. The slowdown can be due to the effect of the anticorruption campaign that 
began in 2013, or to the effect of property and equity market bubbles that may have also had the effect of misallocating financial resources. With more work, it would be very interesting to draw out how much of the growth slowdown is driven by these forces, including the effect of spending by off-balance-sheet companies on behalf of local governments, but this is not a task we undertake in this paper.

The model also rationalizes why the external adjustment in China since 2008 would necessarily be associated with an increase in the investment rate (as opposed to a decrease in the savings rate). As discussed above, the current account surplus (as a share of GDP) starts to decline after 2007. A widely held explanation for the reversal of the current account surplus is that the appreciation of the yuan discourages savings. However, there is only a small decline in the savings rate, and the decline in the current account is entirely driven (in a proximate sense) by the increase in the investment rate. Song, Storesletten, and Zilibotti (2011) explain China's rapidly growing trade surplus before 2009 as the result of domestic financial frictions that suppressed investment. Our argument here is that a similar mechanism is at play, but in reverse. The program to invest 4 trillion yuan and financial deregulation generate an investment boom, which leads to the rebalancing of China's current account.

Finally, the toy model also predicts a rising market interest rate, which is in line with what has been happening in the post-2009 period. This is complementary to explanations of the trends in market interest rates (Hachem and Song 2016). In particular, market-based deposit rates (that is, returns to wealth management products), interbank repo rates, and returns to trust products are all increasing. The model is also consistent with the finding of increasing capital productivity for nonfavored firms that have little access to credit at regulated interest rates.

In sum, the long-run effect of China's temporary fiscal stimulus program appears to have been an increase in the investment rate, a decline in the current account surplus, and a decline in productivity driven by the increased misallocation of resources. Again, we remind the reader that, at least at the time we are writing this paper, GDP growth appears to have slowed compared with the 1990s and early 2000s.

\section{Conclusion}

The central facts about China's economy since 2008 are the slowdown in aggregate growth, the increase in the investment rate, the decline in the external surplus, and the rise in local governments' off-balance-sheet debt. 
We argue that all four facts can be understood as outcomes of the institutions created by the decision to finance the 2009-10 fiscal stimulus with off-balance-sheet spending. This stimulus was largely financed by the creation of off-balance-sheet companies that allowed local governments to circumvent financial controls. About three-quarters of the stimulus spending was done by these off-balance-sheet companies, on behalf of local governments, with only a small increase in the official budget deficit. After the stimulus spending ended, local governments continued to use their newfound power to obtain access to financial resources. The result has been an increase in off-balance-sheet local government debt and an increase in investment spending. Local governments, which have long faced highpowered incentives to support favored local businesses, have used this newfound power to channel financial resources toward favored private firms. The effects on the efficiency of capital allocation may, in turn, have had important effects on aggregate productivity growth in recent years.

Many observers have commented on the rise in China's local government debt as well as the decline in its current account surplus. As an example, in a June 2016 speech widely covered by the media, David Lipton, the IMF's deputy managing director, praised the reversal of China's current account surplus but raised concerns about the rise in debt, including local government debt (Lipton 2016). This paper argues that the rise in local government debt and the external adjustment are two outcomes of exactly the same institutional changes. If this is the case, it is difficult to see how one can praise the external adjustment but condemn the rise in debt. For us, what is more a cause for concern is that the off-balance-sheet institutions may have changed the way the special-deals regime operates. Furthermore, the powerful political forces behind off-balance-sheet lending, combined with the fear of the short-run consequences of shutting down this lending, may make it very difficult to undo LFVs in the future, with potentially significant adverse consequences for China's future growth.

ACKNOWLEDGMENTS We thank the editors Janice Eberly and James Stock, and our discussants, Maurice Obstfeld and Linda Tesar, for extremely helpful comments. We also thank Xueting Wen for excellent research assistance. 


\section{References}

Bai, Chong-En, Chang-Tai Hsieh, and Zheng Song. 2016. "Institutional Foundations of China's Growth." Working paper.

Bai, Chong-En, and Yingyi Qian. 2010. "Infrastructure Development in China: The Cases of Electricity, Highways, and Railways." Journal of Comparative Economics 38, no. 1: 34-51.

Barboza, David. 2008. "China Plans \$586 Billion Economic Stimulus.” New York Times, November 9.

CBRC (China Banking Regulatory Commission). 2009. "Guiding Opinions of the People's Bank of China and China Banking Regulatory Commission on Further Adjusting the Credit Structure to Promote the Rapid Yet Steady Development of the National Economy" [in Chinese]. Document no. 92, March 18. http:// en.pkulaw.cn/display.aspx?cgid=114764\&lib=law

Chang, Chun, Zheng Liu, and Mark M. Spiegel. 2015. "Capital Controls and Optimal Chinese Monetary Policy.” Journal of Monetary Economics 74: 1-15.

Feng, Shuaizhang, Yingyao Hu, and Robert Moffitt. 2015. "Long-Run Trends in Unemployment and Labor Force Participation in China." Working Paper no. 21460. Cambridge, Mass.: National Bureau of Economic Research.

Hachem, Kinda Cheryl, and Zheng Michael Song. 2016. "Liquidity Regulation and Unintended Financial Transformation in China." Working Paper no. 21880. Cambridge, Mass.: National Bureau of Economic Research.

Huang, Yasheng. 2008. Capitalism with Chinese Characteristics: Entrepreneurship and the State. Cambridge University Press.

Huang, Yi, Marco Pagano, and Ugo Panizza. 2016. "Public Debt and Private Firm Funding: Evidence from Chinese Cities.” Working Paper no. HEIDWP10-2016. Geneva: Graduate Institute of International and Development Studies.

IMF (International Monetary Fund). 2016. “The People's Republic of China: 2016 Article IV Consultation-Press Release; Staff Report; and Statement by the Executive Director for the People's Republic of China." Country Report no. 16/270. Washington.

Jiang, Yonghua. 2008. China's Tax Sharing System Reform [in Chinese]. Beijing: China Financial \& Economic Publishing House.

Jin, Hehui, Yingyi Qian, and Barry R. Weingast. 2005. "Regional Decentralization and Fiscal Incentives: Federalism, Chinese Style." Journal of Public Economics 89, nos. 9-10: 1719-42.

Krugman, Paul. 2010. “Keynes in Asia.” New York Times, July 24.

Lipton, David. 2016. "Rebalancing China: International Lessons in Corporate Debt." Speech given at the Conference on Sustainable Development in China and the World, China Economic Society, Shenzhen, June 10.

Ministry of Finance. 2009. "On Speeding Up the Implementation of Local Funding for the Expansion of Domestic Investment Projects" [in Chinese]. Document no. 631, October 12. Beijing: Department of Construction. https://www. scribd.com/document/334087759/On-Speeding-Up-the-Implementation-ofLocal-Funding-for-the-Expansion-of-Domestic-Investment-Projects 
2016. "Finance Minister Lou Jiwei Answers Questions on the Government Debt" [in Chinese]. Press Conference, Beijing, May 26. http://www.mof.gov.cn/ zhengwuxinxi/zhengcejiedu/2016zcjd/201605/t20160526_2037679.htm

NAO (National Audit Office of the People's Republic of China). 2011. "National and Local Government Debt Audit Results" [in Chinese]. Audit Report no. 35, June 27. Beijing.

. 2013. "Audit Results of Nationwide Governmental Debts" [in Chinese]. Audit Report no. 32, December 30. Beijing.

National Development and Reform Commission. 2009. "Focus and Funding Estimates for the Planned 4 Trillion Yuan Investment" [in Chinese]. March 6. Beijing. http://www.gov.cn/gzdt/2009-03/06/content_1252229.htm

Song, Zheng, Kjetil Storesletten, and Fabrizio Zilibotti. 2011. "Growing like China." American Economic Review 101, no. 1: 196-233.

. 2014. "Growing (with Capital Controls) like China." IMF Economic Review 62, no. 3: 327-70.

Song, Zheng (Michael), and Guiying Laura Wu. 2015. "Identifying Capital Misallocation." Working paper. http://www.ntu.edu.sg/home/guiying.wu/ SW_Misallocation_201501.pdf

State Council. 2014. "Opinions of the State Council on Strengthening the Administration of Local Government Debts" [in Chinese]. Document no. 43, September 26. http://jrs.mof.gov.cn/ppp/zcfbppp/201410/t20141031_1155344.html

2015. "Properly Solving the Subsequent Financing Problems of the Projects under Construction by the Local Government Financing Vehicles" [in Chinese]. Document no. 40, May 11. http://www.gov.cn/zhengce/content/ 2015-05/15/content_9760.htm

Wong, Christine P. W., and Richard M. Bird. 2008. "China's Fiscal System: A Work in Progress." In China's Great Economic Transformation, edited by Loren Brandt and Thomas G. Rawski. Cambridge University Press.

Zhou, Xiaochuan. 2004. "Improving the Legal System and Financial Environment" [in Chinese]. Speech given at the Chang' an Forum, Chinese Economists 50, Beijing, December 2. http://magazine.caixin.com/2004-06-05/100093447.html Zhu, Rongji. 2011. “The Record of Zhu Rongji's Words, Volume 2" [in Chinese]. Beijing: People's Publishing House. 


\title{
Comments and Discussion
}

\author{
COMMENT BY
}

MAURICE OBSTFELD This very interesting paper by Chong-En Bai, Chang-Tai Hsieh, and Zheng Song illustrates that it often requires detective work to figure out what is actually going on in the Chinese economy. The authors have therefore provided a public good by taking on this project. The paper effectively illuminates the roots of one of the more worrying trends in contemporary China: the very high level and rapid continuing growth of domestic credit.

Before discussing specific points in the paper, I want to stress how important China's economic growth has become in determining worldwide growth. As shown in my figure 1, the U.S. contribution to global growth has been shrinking over the years, while the Chinese contribution has been rising. And this rise reflects the confluence of two factors: (i) China's growth is relatively high compared with that of the rest of the world; and (ii) because of this, the weight of China in the calculation keeps increasing. In addition to being big, there are multiple channels for events in China to spill abroad some of which have also become more prominent over time. Hence, what happens in China definitely does not stay in China-which is why this paper's topic is so important: China's countercyclical fiscal expansion in response to the global financial crisis, and the resulting aftershocks, have been globally consequential.

The paper's storyline focuses on the global financial crisis and on China's response of undertaking an investment stimulus. However, budget laws prevented on-budget financing of the government's investment plans. So, as Bai, Hsieh, and Song document, the country's local authorities were given the green light to set up local financing vehicles (LFVs) for this purpose. These LFVs were mandated to finance some centrally chosen projects, but they were also able to pick projects of their own. A central claim of 
Figure 1. Contributions of Selected Countries and Regions to Worldwide GDP Growth, 2000-16

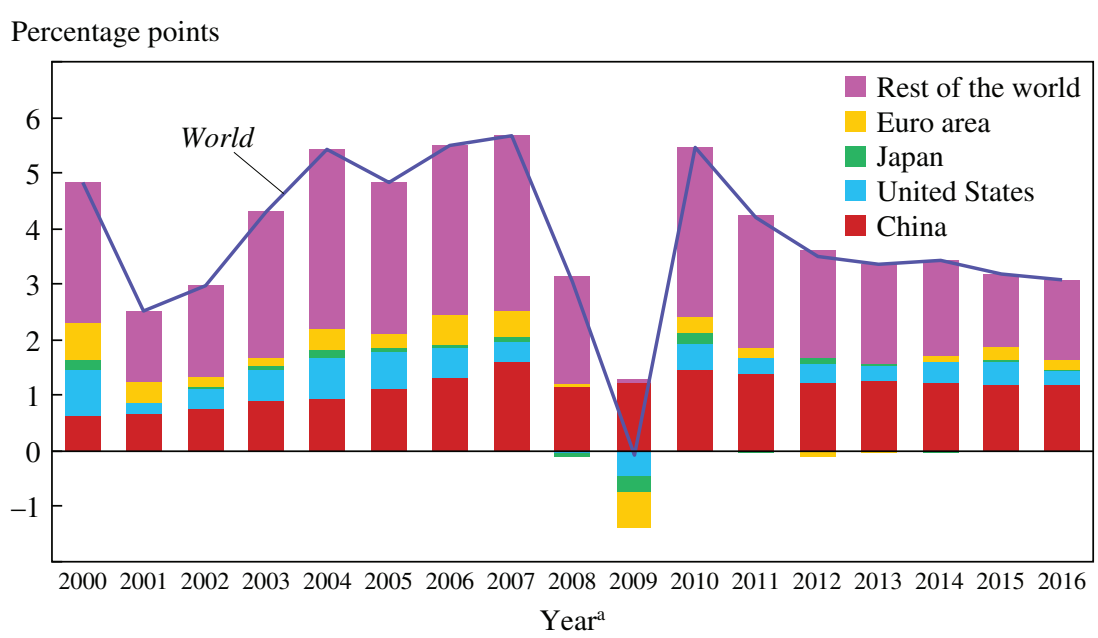

Sources: World Economic Outlook (October 2016); IMF staff estimates. a. Data for 2016 are a projection as of October 2016.

the paper is that this system led to favoritism, to socially suboptimal projects being chosen, and thus to a tax on the economy's overall efficiency and possibly on its overall growth. After the crisis, moreover, China's government failed to rein in the LFVs. Only in 2015 did the government pass a new budget law in an attempt to put more of this debt on the official books, and also to finally control the LFVs. Reportedly, however, their borrowing has nonetheless continued.

I agree with most of the paper. I take issue with one conclusion, however. The paper comes close to implying that the significant slowdown of Chinese growth in recent years is a direct consequence of the fiscal response to the crisis and the failure to fully reverse it. But the evidence presented to support this causality is thin. I read the record somewhat differently. If one looks at the broad totality of recent Chinese developments, it is clear that LFV activity is likely an element, as the authors state; but as they also point out, many other factors are at work as well. The country's growth slowdown has been so sharp that I find it hard to see misallocations from local government borrowing as quantitatively important enough to be the main driver. But this issue certainly deserves further research.

Let me first present some evidence supportive of the authors' narrative. The International Monetary Fund's annual Article IV consultations on the 
Figure 2. China's Fiscal Balances, 2001-16

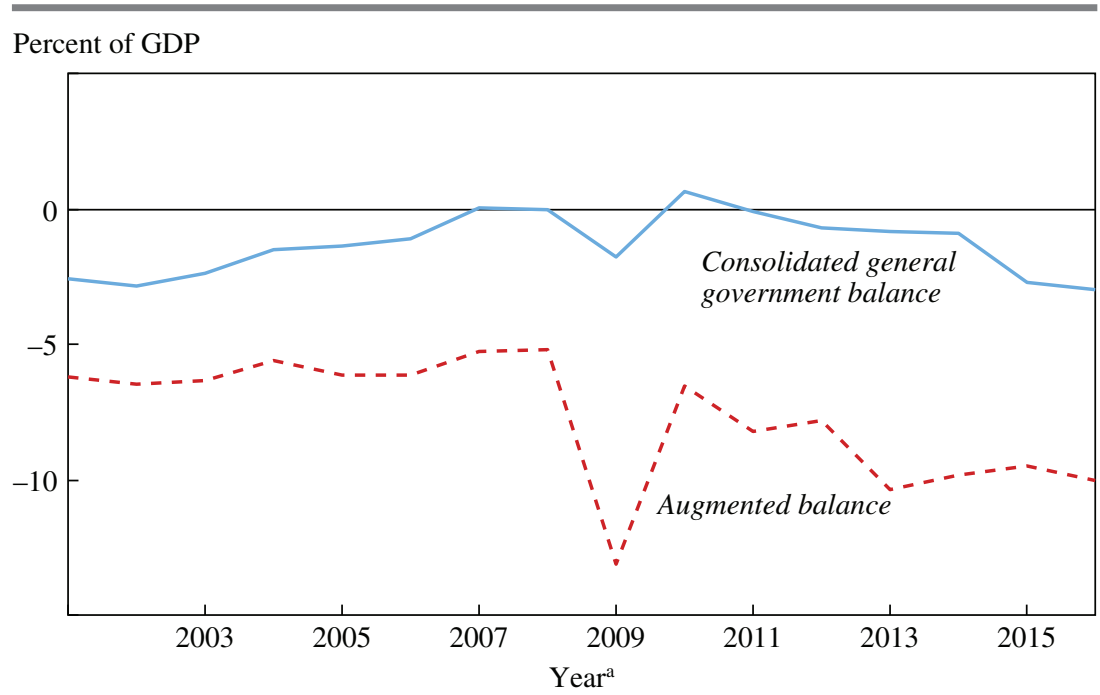

Sources: CEIC Data; IMF staff estimates.

a. Data for 2016 are a projection as of October 2016.

Chinese economy publish both a consolidated general government balance (the solid line in my figure 2), which is the official balance, and also what we call the augmented balance (the dashed line in my figure 2). In order to get this augmented balance, we include as best we can any off-balancesheet borrowing by the general government. However approximate this augmented balance may be (and it differs somewhat from the authors' numbers), it is our best guess; and if one takes it as a reasonable expected value, one can see the big gap between the deficit shown by the augmented balance and that shown by the official general government balance.

According to this augmented balance, China is currently running a fiscal deficit of about 10 percent of GDP, far above the official deficit. A gap was clearly there before the global financial crisis; the fiscal response to the crisis did not create the gap. As the authors document, however, the gap ballooned during the crisis, and then, as they also document, it never returned to the precrisis level. The gap has remained wide, despite a possible hint of some narrowing recently because of the new budgetary law. All this is very consistent with the story the authors tell.

The other element that is consistent with their story is the data on firms' profitability. Here, as shown in my figure 3 , a worrisome trend has appeared: In the private industrial sector, starting in about 2011, profitability has 
Figure 3. The Profitability of State-Owned and Industrial Private Enterprises, 2002-15

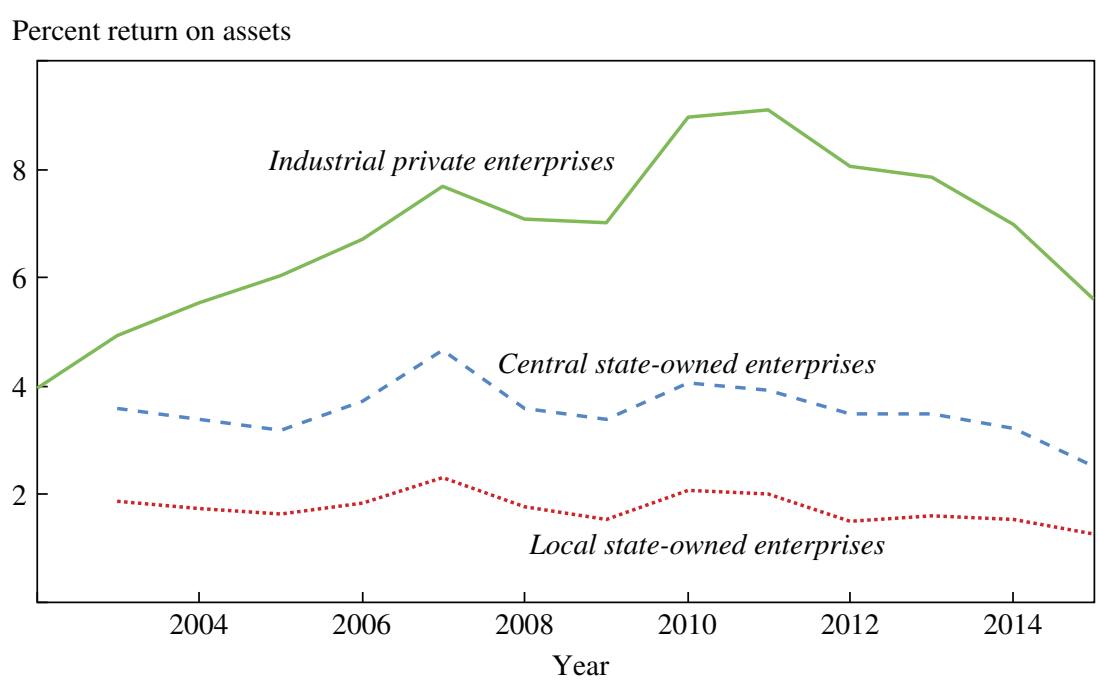

Sources: CEIC Data; IMF staff estimates.

seemed to be falling sharply. It is higher in the private sector than in the state-owned sector, and, consistent with the authors' story, central stateowned enterprises are more profitable than local state-owned enterprises. Profitability in the state-owned sector, which was already quite low, has also declined since the stimulus, but not as sharply as in the private sector.

What is going on here? One culprit could be the general allocation of credit in the Chinese economy. My figure 4 breaks out total domestic credit growth, called total social financing, into the share due to local financing vehicles and the rest. ${ }^{1}$ LFV financing has clearly grown quickly in the postcrisis period, but so has other domestic credit. Domestic credit in China is high relative to levels in peer emerging market economies; in fact, it has reached levels that would be consistent with elevated crisis probabilities in other peer economies. Not only is the LFVs' borrowing possibly being misallocated, so also is some of the other credit, because it is passing through state-owned banks or shadow banks that in some cases are influenced by distorted incentives. Banks are an important lever for official control of the economy, and the Chinese financial system is famously opaque. Credit

1. The coverage of the LFV data in this figure seems to be more restrictive than what the authors show in their figure 6 . 
Figure 4. Domestic Credit in China, 2008-15

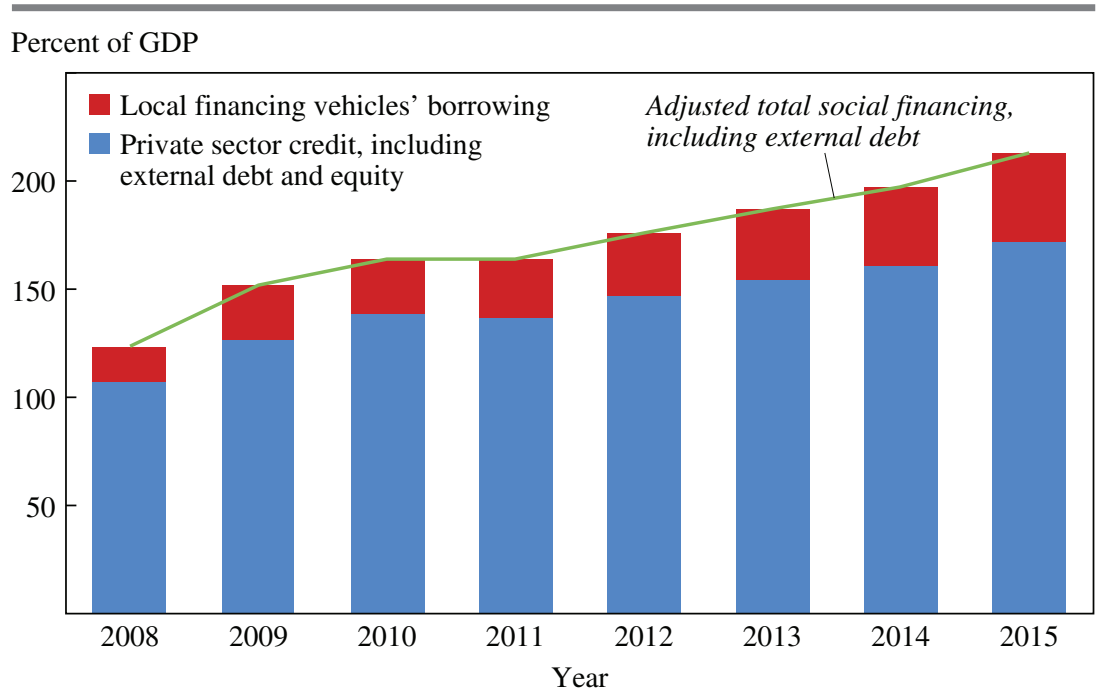

Sources: CEIC Data; IMF staff estimates.

misallocation beyond that due to LFVs thus could be exacerbating declining profitability and slower growth.

A key development in China since the stimulus has been a concerted effort to rebalance the aggregate economy away from investment and toward consumption, and into services and out of traditional industry and manufacturing. The results are shown clearly in my figure 5, and this pattern is also consistent with the authors' figure 1. Investment peaks in 2011; afterward, there is a pullback from construction and infrastructure as the rebalancing process unfolds. One much-noted result has been an overall deceleration of economic growth.

To some degree, this rebalancing process is a natural result of higher real wages and a growing middle class; and to some degree, it is statemanaged. Lower growth may simply follow from the expansion of inherently less productive nontraded sectors of the economy. But another result has been excess manufacturing capacity, which has made China's trading partners, including the United States and Europe, quite unhappy, and arguably has contributed to global deflationary pressures in some sectors. This excess capacity, prolonged by the domestic credit allocation process, has surely exacerbated the Chinese economy's overall lackluster productivity performance and helped push growth lower. At this point, there is a significant nonperforming loan problem in the country's bank- 
Figure 5. GDP by Type of Industry, 2008-15

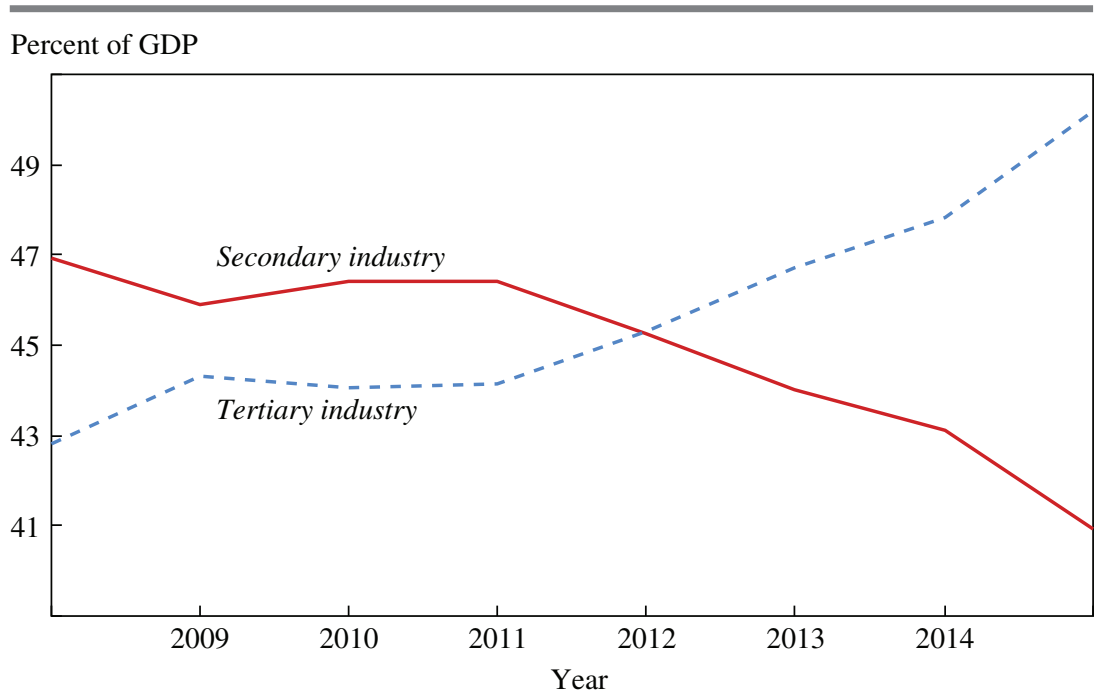

Sources: CEIC Data; IMF staff estimates.

ing system, which is crowding out better lending prospects, as Bai, Hsieh, and Song explain.

Credit misallocation is surely hurting potential growth; but it is also likely that without some of the measures China's government is currently undertaking — measures that reprise, on a smaller scale, some of what was done during the crisis_realized growth would actually now be lower. The authorities have been determined to hit an official, politically mandated growth target of between 6.5 and 7 percent a year. But to do this, they are returning to infrastructure spending and credit growth in a way that may simply store up problems for later.

I want to come back to my first point-about China being systemically important - while at the same time providing more evidence on China's current transition process. One indication of a big shift in economic orientation in about 2011 was the behavior of global commodity prices. China consumes very high shares of the world's base metal production, in some cases more than 50 percent. When its economy started to shift away from infrastructure, construction, and other investment in about 2011, these commodities' prices began to fall in world markets. ${ }^{2}$ In turn, this terms-of-trade

2. Commodity prices had dropped in the crisis and then recovered with China's stimulus; but since then, they have fallen. 
decline has confronted emerging and developing commodity exporters, which had invested heavily in extractive capacity, with a serious adjustment problem. In fact, it is now clearer to what degree commodity exporters' growth performance since the early 2000s has been driven by China. It is telling that China's recent stimulus measures have also allowed some commodity prices to firm up. But this relief could be temporary. China has work ahead to resolve its domestic imbalances; and absent vigorous action, the rest of the world could be in for a bumpy ride.

\section{COMMENT BY}

LINDA TESAR During the 2009-10 period, the Chinese government undertook a massive fiscal expansion on the order of 12 percent of annual GDP, dwarfing the magnitude of the fiscal response in other countries. During the same period, the increase in government expenditures in the United States and the euro area was roughly 1 percent as a share of GDP. ${ }^{1}$ The long shadow described by Chong-En Bai, Chang-Tai Hsieh, and Zheng Song in their paper is that the fiscal expansion in China produced a large increase in aggregate investment, but this expansion was financed by offbalance-sheet companies that lent to firms with close connections to local government authorities. These firms, in turn, invested in inefficient projects, ultimately hurting China's prospects for growth.

The strength of this paper is its forensic analysis of the balance sheets of the central and local governments and the financial sector, including the shadow banks. The data suggest that the fiscal stimulus was made possible by a relaxation of the balanced-budget constraint on local governments. Local governments set up local financing vehicles (LFVs), which were able to borrow and make loans to private firms. These loans, in turn, were used to undertake large-scale infrastructure projects as well as private commercial ventures, boosting aggregate investment. The paper argues that even after the Chinese economy was on the path to recovery, local governments continued to use LFVs to provide financial resources to favored firms. About three-quarters of the off-balance-sheet spending was allocated

1. Fiscal stimulus as a share of GDP is the increment of government purchases between 2008 and 2010, divided by 2009 GDP. For China, it is the fiscal stimulus in 2009 and 2010 from Bai, Hsieh, and Song's table 1, divided by 2009 GDP. Government purchases for the United States are measured by government consumption expenditures and gross investment (U.S. Bureau of Economic Analysis, National Income and Product Accounts, table 1.1.5, "Gross Domestic Product"), and for the euro area it is final consumption expenditures of general government (Eurostat code tec00010, http://ec.europa.eu/eurostat). 
Figure 1. Real GDP Growth, 2000-16

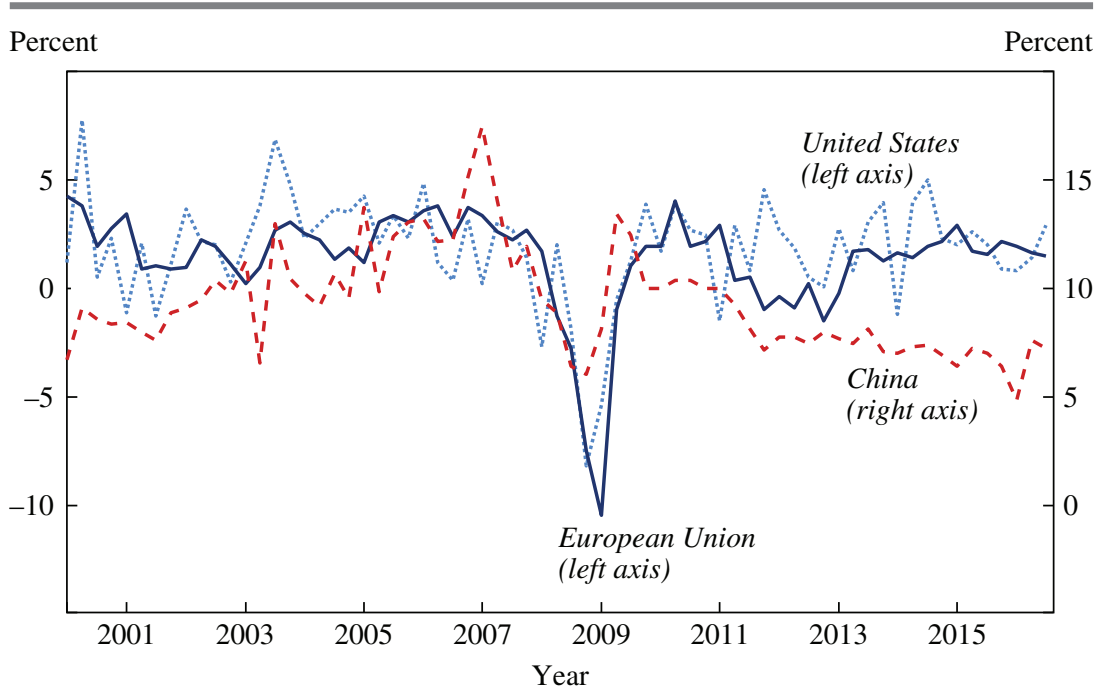

Sources: Federal Reserve Economic Data; Chang and others (2016).

a. Real GDP growth is measured as the percent change over the preceding quarter, seasonally adjusted, at annual rates.

to private commercial projects. The paper further argues that because the firms undertaking these projects are inefficient, the ultimate outcomes were a misallocation of capital and a permanent decline in productivity and GDP growth.

To put China's growth in perspective, it is helpful to compare its recent experience with that of the United States and Europe. My figure 1 shows growth in real GDP for 2000-16. As a rapidly growing emerging market, China has a growth rate that is much higher than those of industrialized countries. The figure has a dual scale, with China's growth rate indicated on the right axis, and the European Union and the United States on the left axis. China's growth rate increased before the crisis, peaking in the first quarter of 2007. Then, China experienced the global financial crisis along with the rest of the world, and though its growth rate returned to its precrisis level in mid-2009, it declined fairly steadily thereafter. One interpretation of the data in figure 1 is that China-like many emerging markets-has a low capital-output ratio, and is growing quickly as it converges toward the steady-state growth path of advanced economies. In this view, the gradual slowing of growth is a reflection of convergence that 
is likely to continue into the future. An alternative view-and the one put forward by Bai, Hsieh, and Song-is that China's aggressive fiscal policy is responsible for its decline in growth after 2011. The fiscal stimulus may have softened the blow of the global financial crisis in China; its recession was less severe than those of the United States and Europe. The cost, however, was that China's stimulus resulted in an inefficient allocation of capital, which casts its "long shadow" of subsequent lower growth rates through 2016.

Following the global financial crisis, many policymakers and global institutions advocated for the sort of aggressive fiscal policy undertaken by the Chinese government. In early 2009, the position of the International Monetary Fund was that fiscal policy must play a central role in supporting demand. The IMF chided the G-20 countries for stimulus programs that fell short of its recommended target of 2 percent of GDP. The IMF (2009, p. 17) further advocated that the composition of the fiscal stimulus was as critical as its size: "The key is to ensure that fiscal initiatives boost activity over the relevant time frame, while seeking lasting benefits to productive capacity. The length and severity of the downturn justifies greater weight on public investment in projects that typically have long lags but bring substantial longer-term benefits." Similarly, the directive issued by the Organization for Economic Cooperation and Development (OECD) on the stimulus asserted that fiscal expansion was necessary not just to support short-term demand but also to encourage long-run growth. The OECD's June 2009 "Report on Strategic Response" recommends that (i) fiscal expansion should focus on infrastructure projects that can be implemented quickly and effectively; (ii) the stimulus should target expenses to idle resources, such as lowskilled youth, women, and older workers; and (iii) policymakers should use existing programs and agencies, such as local governments, to distribute the spending and to ensure that funds are disbursed to parts of the economy that cannot be reached by national agencies and programs (OECD 2009, p. 26).

The aggressive fiscal expansion pursued by the Chinese government appears to have many features of a program that would be endorsed by the IMF and the OECD, though perhaps on a scale that would exceed their recommendations. As Bai, Hsieh, and Song describe in detail in their paper, the fiscal stimulus was implemented through local governments by lifting financial constraints, rather than being directed by the central administration to specific government projects. The funds were channeled to private firms, which in turn invested them partly in infrastructure projects. The stimulus was persistent, lasting well after the worst of the recession had 
passed. To the extent that the stimulus crowded out investment, the evidence suggests that the main impact was on purchases of U.S. Treasury bills by the People's Bank of China, and not on investment by private companies. The increased size and riskiness of the shadow banking sector would likely be a cause for concern among international institutions, and perhaps for the authors, although this is not the primary reason they give for the negative impact on growth.

There is accumulating evidence that a fiscal stimulus has strong effects on economic activity, particularly during recessions and when monetary policy is constrained. In my recent research done with Christopher House and Christian Proebsting, we find evidence of a large multiplier on government purchases in the cross section of European countries in the aftermath of the global financial crisis (House, Proebsting, and Tesar 2016). After controlling for taxes, productivity, and the debt-GDP ratio, we find that countries with more sizable shortfalls in government spending had significantly lower output, consistent with a multiplier of about 2 . This is on the high side of the literature on multipliers in advanced economies-typical estimates are between 0.5 and 1.5 (Auerbach and Gorodnichenko 2013a, 2013b; Batini and others 2014). Estimates of the multiplier in emerging markets tend to be smaller, though still positive (Kraay 2014).

So, if multipliers are generally positive, what went wrong with the fiscal expansion in China? If a company that received a loan through an LFV to invest in a stadium spent 1 yuan (one example given by the authors), this should show up as an increase in investment spending of 1 yuan. The paper asserts that spending of this sort permanently lowers the growth rate of aggregate GDP. According to the authors, the key problem is that the wrong firms ended up as the recipients of subsidized credit. The fiscal stimulus was a partial financial liberalization: Local governments used the additional funds to make loans to inefficient, but "connected," firms. These connected firms borrow up to their limit, crowding out funding to unconnected firms by raising the marginal lending cost. And this rise in marginal lending cost drives a wedge between the marginal products of capital for connected and unconnected firms. Ultimately, this misallocation of capital results in a surge in investment that is not matched by growth in aggregate output. The increase in lending costs for other firms is implied by the model, though this implication is somewhat mechanical and not obvious, at least to me. It seems equally plausible that an increase in funds to the financial sector that is channeled to particular firms could take these firms out of competition for loans, and might even reduce the cost of funding for other firms. 
Bai, Hsieh, and Song present two pieces of evidence in support of a misallocation of capital. The first nugget of evidence is a comparison of the debt-revenue ratios across different types of firms. Listed firms- taken as a proxy for politically connected firms - take on more debt relative to other firms after 2008. Second, there is some evidence of dispersion in the average product of capital across firms, consistent with the wedge in marginal products suggested by the model. There is an inconvenient gap in the data on average products between 2007 and 2011. Nonetheless, there is a hint of an upturn in the dispersion at the end of the sample. Although these indicators point in the right direction, they fall a bit short of being fully convincing that there is a widespread misallocation of capital, and on a scale that would actually diminish long-term growth. Even if the expansion of investment were somewhat inefficient across firms, it is hard to see why this would be bad for growth without a reallocation from good firms to bad firms. In assessing the evidence, the question is not whether some other allocation would have produced faster growth (surely, all government programs fail against that standard), but whether the fiscal expansion as implemented in China through investment in connected firms actually hampered aggregate growth in the long run.

To strengthen their argument, the authors might pursue a number of avenues. One would be to find a better way to identify politically connected firms. Ideally, one would like to identify firms that have a direct link to local government officials, perhaps by using information about membership on boards of directors, or by focusing on firms in those industries or activities that require permits from the government. To support the paper's argument, the evidence should show that these connected firms were credit-constrained before the crisis, that they then received subsidized loans during the fiscal expansion, and that they are less productive than other firms. The evidence on the average product of capital should show that the dispersion remains after controlling for risk, and that there is a wedge between connected and unconnected firms in the direction predicted by the model. The analysis could also exploit cross-provincial variation in China to show that in areas where firms are more influenced by the government, spending increased and the multiplier was lower (Nakamura and Steinsson 2014).

Overall, this is a fascinating paper that contains a wealth of information about fiscal policy and growth in China. The authors are surely right that the policy's implementation was less than efficient. Whether this inefficiency was large enough to cast such a long shadow through the mechanism they suggest remains an open question. 


\section{REFERENCES FOR THE TESAR COMMENT}

Auerbach, Alan J., and Yuriy Gorodnichenko. 2013a. "Fiscal Multipliers in Recession and Expansion." In Fiscal Policy after the Financial Crisis, edited by Alberto Alesina and Francesco Giavazzi. University of Chicago Press.

—. 2013b. "Output Spillovers from Fiscal Policy." American Economic Review 103, no. 3: 141-46.

Batini, Nicoletta, Luc Eyraud, Lorenzo Forni, and Anke Weber. 2014. "Fiscal Multipliers: Size, Determinants, and Use in Macroeconomic Projections." Technical Notes and Manuals no. 14/04. Washington: International Monetary Fund.

Chang, Chun, Kaiji Chen, Daniel F. Waggoner, and Tao Zha. 2016. "Trends and Cycles in China's Macroeconomy." NBER Macroeconomics Annual 30: 1-84.

House, Christopher L., Christian Proebsting, and Linda Tesar. 2016. "Austerity in the Aftermath of the Great Recession." Working paper. http://www-personal. umich.edu/ ltesar/pdf/austerity.pdf

IMF (International Monetary Fund). 2009. "Global Economic Policies and Prospects." Staff note, Meeting of the Ministers and Central Bank Governors of the Group of Twenty, London, March 13-14. https://www.imf.org/external/np/g20/ pdf/031909a.pdf

Kraay, Art. 2014. "Government Spending Multipliers in Developing Countries: Evidence from Lending by Official Creditors." American Economic Journal: Macroeconomics 6, no. 4: 170-208.

Nakamura, Emi, and Jón Steinsson. 2014. "Fiscal Stimulus in a Monetary Union: Evidence from US Regions." American Economic Review 104, no. 3: 753-92.

OECD (Organization for Economic Cooperation and Development). 2009. "Report on Strategic Response: Strategies for Aligning Stimulus Measures with LongTerm Growth." Document no. C/MIN(2009)9/ANN2, Meeting of the Council at Ministerial Level, Paris, June 24-25. https://www.oecd.org/general/ 42555546.pdf

GENERAL DISCUSSION Alice Rivlin found herself wondering whether, institutionally, there were some lessons that the United States could learn from China regarding infrastructure investment by local governments. She noted that the United States is facing what is widely acknowledged to be an infrastructure deficit, and a deficit in future productivity generally, but that policymakers are reluctant to finance it by expanding the federal debt. She contended that most economists would probably approve of expanding the federal debt to finance infrastructure projects; conversely, given the current political climate, policymakers would be very hesitant to do so. If the U.S. government were to establish new financial institutions at the local level, they might be called "public-private partnerships," or "local infrastructure banks." Though such institutions might not always make optimal decisions, nobody does, and U.S. policymakers certainly are not 
making them now. As a case in point, a recent exposé by authors at the Brookings Institution examined how the federal government subsidizes the construction of professional sports facilities through local governments' use of tax-exempt municipal bonds. ${ }^{1}$

Gert Peersman noted that the situation described in the paper is not unique to China. Such financing vehicles are also utilized in Europe to avoid certain budget rules implemented by the European Union. He noted that regions and even countries use these vehicles. Belgium, for example, uses local investment vehicles to build schools, while the federal government guarantees the flow of funds. He added that the cost of funding is actually slightly more expensive than if the federal government were to invest directly, because local governments must pay a fee to use the service; but it turns out that it is more efficient because these kinds of local financing vehicles tend to stick better to their budgets. So the story is not entirely negative. However, the European Commission has started to roll back and consolidate these entities, so European countries will need to find other ways to encourage investment.

Narayana Kocherlakota thought that the paper was fascinating, and said that it made him think about the world economy differently. Rather than thinking about the world economy from the point of view of a U.S. policymaker, he began to think about it from the point of view of a Chinese policymaker. With so much excess capacity in China, a Chinese policymaker might wonder why the West does not grow a little faster and thus stimulate some demand, so China can use up that excess capacity. The big disappointment, from the perspective of a Chinese policymaker, he noted, must be the failure of the West (including Japan) to grow rapidly enough. Because of this lack of demand, China is forced to accelerate the transition to internal sources of demand, and to do it in a very difficult way, all because of the fact that Europe, Japan, and the United States are not growing at a rate that China was hoping or expecting. China's slow growth problem since 2011 could well be related to the United States' slow growth problem, he concluded.

Chang-Tai Hsieh had noted in his presentation that China ranks near the bottom on the World Bank's Doing Business indicators when it comes to the ease of starting a business, and described how local financing vehicles were used to help facilitate the circumvention of those barriers for favored

1. Ted Gayer, Austin J. Drukker, and Alexander K. Gold, "Tax-Exempt Municipal Bonds and the Financing of Professional Sports Stadiums," Brookings Institution report, September 2016. 
Chinese firms. ${ }^{2}$ Steven Davis called this "another shadow of the whole system," suggesting that such arrangements might entrench political interests that want to preserve harsh barriers to business formation and growth outside the special treatment class. He wondered if removing such barriers for firms that are not politically connected has become harder because doing so would undermine the chief way that local public officials enrich themselves. He suggested that this might have implications outside China, and is potentially a danger of providing certain firms with special treatment.

Benjamin Friedman wanted to reinforce a point made by discussant Linda Tesar regarding the issue of whether the relevant counterfactual would be that, absent the Chinese government's fiscal intervention, (i) somebody would be investing in more productive projects, or (ii) no one would be investing at all. This question is a piece of the more generic, but parallel, issue that pervaded discussions of the multiplier in the United States in the early 2010s. He noted that much of that analysis had the flavor of assuming that if people were not being employed by whatever governments were spending on, they would necessarily be working somewhere else. The relevant issue, under that assumption, was the productivity of the activity they were undertaking with the government funding versus the productivity of what they would be doing otherwise. This is contrary to the 1930s' Great Depression-oriented thinking that dominated for many decades, which recognized that, in fact, without the government hiring, people would be sitting home doing nothing. While the truth is presumably somewhere in between, in Friedman's view, the "doing nothing" assumption is probably the right one for the United States. He concluded that establishing which is right for China would be a useful contribution.

Gerald Cohen took issue with Tesar's implication that a misallocation of capital is a second-order effect. He argued that a misallocation of capital with large balance sheet implications-such as the U.S. housing boom in the mid-2000s—could have substantial first-order implications for growth. Capital misallocation in China, he thought, might have substantial firstorder implications, which he suspected is what has many people worried.

Going back to the question of the relevant counterfactual, James Stock stated that the implicit presumption in the paper is that, barring these misallocations, China today would have been at its growth level of the early 2000s. He questioned whether this was a correct assumption, noting that

2. The World Bank ranks economies on their ease of doing business based on a variety of factors, with 1 representing the most ease in doing business. China ranked 151 out of 185 in 2013 in terms of the ease of "starting a business." 
after the 2007-09 recession, international growth was slower and labor costs rose. Assuming more modest growth in the counterfactual would change the framing of the conversation.

Hsieh responded first by saying that the present paper did not intend to say anything about the fiscal stimulus and the consequences of spending on infrastructure. Furthermore, the authors' argument is not about the efficiency of the spending that took place in 2009 and 2010. Rather, the paper's main argument is about the changes in the underlying institutions that the stimulus brought about. Some of this shows up in continued investment in infrastructure, he said, but what one really starts to see is that investment in infrastructure becomes a very small share of what the local financing vehicles are doing. By 2015, most of the spending by the local financing vehicles was on state-owned and private firms" "commercial projects."

Building on the point made by Davis, Hsieh agreed that the "other shadow"-and potentially, the more important shadow-is the role that local government officials play in helping favored private firms navigate the dysfunctional formal institutions. These officials have a vested interest in making sure that they continue to be needed. He explained that probably the most important force behind the slowdown in growth is that when President Xi Jinping came to power in the fall of 2012, his main agenda was the crackdown on corruption. ${ }^{3}$ Local government officials in charge of the local financing vehicles depend on the status quo system for everything. Hsieh explained that, before Xi's coming to power, these local officials could basically do whatever they wanted. Since the local financing vehicles do not have access to tax revenue, which is centralized, the only way for the local officials to get paid was if their companies were successful. There was a social contract that was clear to everyone who was involved in the system: If the companies did well, the local officials would be compensated in some way; in some cases, they would even be given equity.

As Davis suggested, the solution is to change the institutions so that these local government officials are not needed anymore. In the first two years of $\mathrm{Xi}$ 's presidency, that is exactly what happened; understandably, there was resistance from local public officials. However, Hsieh had observed that this particular part of Xi's agenda has now fallen by the wayside.

3. See, for instance, Xi's November 15, 2012, speech before the members of the Politburo Standing Committee (http://www.bbc.com/news/world-asia-china-20338586). 
In response to Tesar's and Cohen's questions about the effects of misallocation, Hsieh noted that, though the authors probably could say more about them, they did not feel that these effects were the value added by the present paper; rather, the paper seeks to lay out the story behind how local financing vehicles have changed over time. The way one should think about misallocation is not as the allocation of resources to inefficient firms, but rather as the allocation of resources such that the gap in the return to resources across firms is increased. He noted that one could very well have a scenario in which resources are allocated to the most efficient firms (this may well be the scenario in China today, he noted), but too many resources are allocated to them. Hsieh observed that the most efficient firms are really the cronies; they are efficient but are receiving more capital than that dictated by the return on all the other firms' projects. 